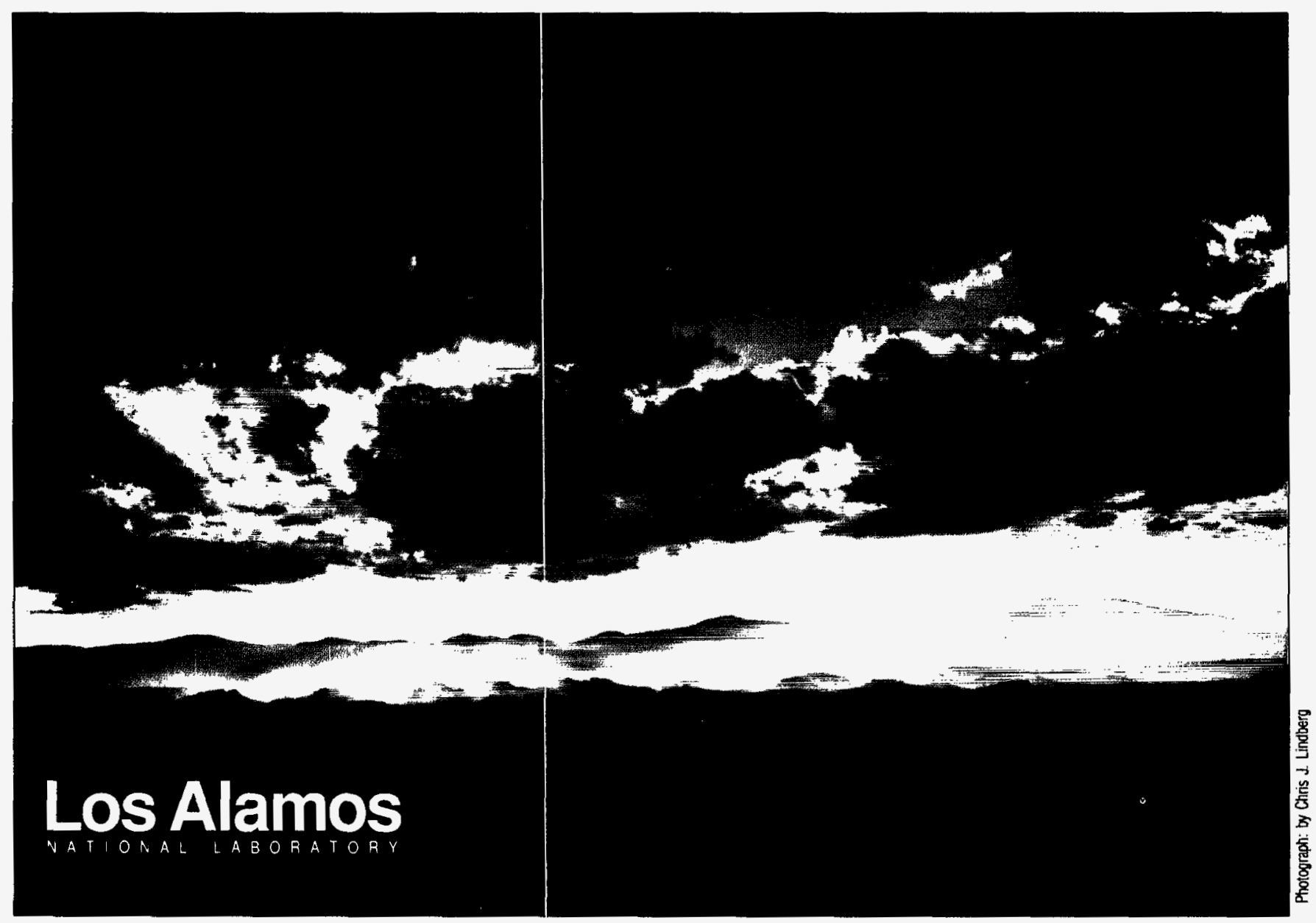

Los Alamos National Laboratory, an affirmative action/equal opportunity employer, is opetated by the University of California for the U.S. Department of Energy under contract W-7405.ENG-36. By acceptance of this article, the publisher recognizes that the U.S. Government retains a nonexclusive, royaliy-free license to publish or reproduce the published form of his contribution, or to allow others to do so, for U.S. Covernment purposes. The Los Alamos National Laboratory requests that the publisher identify this article therefore, the Laboratory as an institution does not endorse the viewpoint of a publication or guarantes its technical correctness. 


\section{$L A-4 R=-98-103$}

\section{TASK COMPLETION REPORT}

\section{FOR UPDATE FXTIME}

by

Robert G. Steinke

August 29, 1997

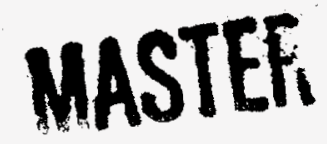




\section{DISCLAIMER}

This report was prepared as an account of work sponsored by an agency of the United States Government. Neither the United States Government nor any agency thereof, nor any of their employees, makes any warranty, express or implied, or assumes any legal liability or responsibility for the accuracy, completeness, or usefulness of any information, apparatus, product, or process disclosed, or represents that its use would not infringe privately owned rights. Reference herein to any specific commercial product, process, or service by trade name, trademark, manufacturer, or otherwise does not necessarily constitute or imply its endorsement, recommendation, or favoring by the United States Government or any agency thereof. The views and opinions of authors expressed herein do not necessarily state or reflect those of the United States Government or any agency thereof. 


\section{DISCLAIMER}

Portions of this document may be illegible electronic image products. Images are produced from the best available original document. 


\title{
TASK COMPLETION REPORT FOR UPDATE FXTIME
}

\author{
Robert G. Steinke
}

\begin{abstract}
The DSTEP $=-99$ and TIMET $\geq 0.0 \mathrm{~s}$ feature in TRAC-P has been tested on the W4LOOP and W4LOOPR standard test problems and was found to give different W4LOOPR solutions for different values of TIMET when all these cases should have given the same solution. Update FXTIME has corrected part of the cause of that difference and reduced the difference by an order of magnitude. The error associated with the remaining difference has been documented in Trouble Report 238.
\end{abstract}

\subsection{INTRODUCTION}

Knolls Atomic Power Laboratory (KAPL) requested the TRAC-P feature of inputting a problem time TIMET $\geq 0.0 \mathrm{~s}$ to replace the problem time from the last restart-data dump when DSTEP $<0$. That capability was found to already exist in TRAC-P when DSTEP $=-99$ is input but not documented. KAPL requested that this undocumented capability in TRAC-P be tested to verify that it functioned correctly and that it be documented appropriately.

\subsection{INITIAL TESTING}

The W4LOOP and W4LOOPR standard test problems were used to perform this test because the W4LOOPR transient calculation is restarted from the last restart-data dump of the W4LOOP steady-state calculation. The power vs absolute time component-action table of ROD 140 with NRPWTB $=20$ in W4LOOP was changed to a power vs relative-time table with NRPWTB $=-20$. This was done so that changing TIMET in W4LOOPR would not require changing the 20 time values in the W4LOOP power table and reevaluating W4LOOP for each W4LOOPR calculation.

W4LOOPR is expected to give the same transient solutions for DSTEP $=-1$ or -99 and TIMET $=0.0 \mathrm{~s}$ and for DSTEP $=-99$ and TIMET $\geq 0.0 \mathrm{~s}$. Testing W4LOOPR with DSTEP $=-1$ or -99 and TIMET $=0.0 \mathrm{~s}$ gave identical transient solutions. Testing W4LOOPR with DSTEP $=-99$ and TIMET $=0.0,0.0001,0.01,1.0,100.0$, or $10000.0 \mathrm{~s}$ gave different transient solutions in each case. The major cause of this difference was traced to an error in the TIMET $>0.0 \mathrm{~s}$ cases of evaluating the valve flow-area fraction vs relative time table of VALVE component 6 (with a $\Delta \mathrm{t}$ shift in the table's time abscissa coordinate values) during the first timestep as well as in all cases of evaluating the power table of ROD 140 (with a $\Delta t$ shift in the table's time abscissa coordinate values) during the first timestep. The valve-table evaluation opens the 
valve-interface flow area of VALVE 6 from an initially closed state from time 0.0 to $0.1 \mathrm{~s}$ to simulate a cold-leg pipe large break. The power-table evaluation of ROD 140 defines the reactor-core power of all fuel rods. These valve and power tables don't have trip control because their component actions are evaluated every timestep of the W4LOOPR transient calculation.

The nature of the above error is unique to evaluating a nontrip-controlled, relative independent-variable, component-action table when DSTEP $=-99$ and TIMET $>0.0 \mathrm{~s}$. The error occurs during the first timestep and was found to affect all component actions.

\subsection{UPDATE FXTIME}

Update FXTIME, a listing of which is shown in Appendix A, was programmed to correct this error in TRAC-P Version 5.4.28. The error centers on evaluating nontrip-controlled, relative independent-variable, component-action tables with source code specifying TLAPS = DTO for the component actions of BREAK, FILL, HTSTR (ROD or SLAB), PIPE, PUMP, TEE, and TURB components and TLAPS = AMIN1(DTO, ETIME) for the component action of the VALVE component. During the first timestep, TLAPS $=$ DTO performs a $\Delta t$ shift in the power table's abscissacoordinate time values, and TLAPS = AMIN1(DTO, ETIME) performs a $\Delta t$ shift in the valve table's abscissa-coordinate time values when TIMET (defining ETIME) is input with a value $>0.0 \mathrm{~s}$ ( $\geq \mathrm{DTO})$. In general, the relative table's $\Delta$ shift of its independent variable is the independent-variable parameter's value change during the TLAPS change in problem time.

For an initial (nonrestart) steady-state or transient calculation or for a steady-state or transient calculation restarted from a steady-state calculation data dump, no shift in the relative table's independent variable should be done during the first timestep. It only should be done during the first timestep of a transient calculation restarted from a transient-calculation data dump. Thus, the TLAPS = AMIN1(DTO, ETIME) defining form for the valve table does this correctly with TLAPS $=0.0 \mathrm{~s}$ when ETIME $=0.0 \mathrm{~s}$ for an initial calculation, for a restart calculation from the last data dump of a steady-state calculation, or for a selected data dump of a steady-state calculation where TIMET $=0.0 \mathrm{~s}$ is input. TLAPS = DTO for all the other component actions should have been defined this way. But when

ETIME $>0.0 \mathrm{~s}$ is the problem time from all but the last data dump,

TIMET $>0.0 \mathrm{~s}$ is input to replace ETIME $>0.0 \mathrm{~s}$ from all but the last data dump,

or TIMET $>0.0 \mathrm{~s}$ is input to replace ETIME $=0.0 \mathrm{~s}$ from the last data dump of a steady-state calculation, then

TLAPS = AMIN1 (DTO, ETIME) does the relative table's $\Delta$ shift of its independent variable during the first timestep (when it should not) because TLAPS $=$ DTO.

To correct this, update FXTIME programs TLAPS $=$ DTO ${ }^{*}$ FLOAT(MINO(1, ITRANS + NSTEP)) as a replacement for TLAPS = DTO in subroutines BREAKX, EVFXXX, FILLX, PUMPSR, and TRBPRE and as a replacement for TLAPS = AMIN1(DTO, 
ETIME) in subroutine VLVEX. ITRANS is the value of the input transientcalculation indicator TRANSI $(0=$ no transient calculation, $1=$ transient calculation $)$ from the previous calculation read from the restart data dump. ITRANS $=0$ is initialized in subroutine INPUT for a steady-state or transient initial (nonrestart) calculation. TRANSI is written to the TRCDMP file by subroutine DMPIT and read from the TRCRST file as ITRANS by subroutine RDREST for steady-state or transient restart calculations. NSTEP is the timestep number stored in common block ISTAT (Comdeck ITERSTAT). NSTEP is 0 during the first time step and is incremented by 1 at the end of each timestep to count a successfully completed timestep. During the first timestep when NSTEP $=0$ and ITRANS $=0$ for an initial calculation or restart calculation from the data dump of a steady-state calculation, TLAPS $=\mathrm{DTO}^{*}$ FLOAT $(\mathrm{MINO}(1,0+0))=0.0 \mathrm{~s}$. For all other timesteps when NSTEP > 0 and/or when ITRANS $=1$ (transient calculation restarted from the data dump of a transient calculation), TLAPS $=$ DTO $*$ FLOAT $($ MINO $(1,(0+>0)$ or $(1+0)$ or $(1+>0)))=$ DTO. This is shown in Table I for all nine combinations of a present steady-state (SS) and/or transient (TR) calculation, which is an initial calculation or restarted from a previous steady-state and/or transient calculation.

Two other errors were found that are corrected by update FXTIME. The first error also affects the DSTEP $=-99$ and TIMET $>0.0 \mathrm{~s}$ feature, and the second error corrects the defining form for the DELXMX timestep constraint for valve adjustment.

For the first error, QINT is not evaluated IF ((IREST.NE.0).AND.(ABS(TIMET).GE. DTMIN)) is .TRUE. in subroutine IPRIZR during the initialization stage. The IF test assumes DTMIN $<1.0 \mathrm{~s}$ during steady-state calculations where TIMET $=-1.0 \mathrm{~s}$.

There are three situations where the IF test needs to be .FALSE. to evaluate QINT: (1) the second logic argument is .FALSE. for a transient calculation restarted (where the first logic argument is .TRUE.) from the last data dump of a steady-state calculation, (2) the second logic argument is .FALSE. for an initial transient

\section{TABLE I}

TLAPS $=$ DTO*FLOAT $($ MIN0(1, ITRANS+NSTEP) $)$ values for a matrix of initial or restarted steady-state and/or transient calculation cases when NSTEP $=0$ for the first timestep $($ TLAPS $=$ DTO when NSTEP $>0$ ).

Case $\ldots$ Calc. STDYST TRANSI Dump

1

2

3

4 SS $>0 \quad 0 \quad$ SS

5 SS $>0 \quad 0 \quad$ SS

6 SS $>0$

7 SS+TR $>0$

$8 \mathrm{SS}+\mathrm{TR}>0$

9 TR 0

$\begin{array}{cccccc}\text { Calc. } & \text { STDYST } & \text { TRANSI } & \text { Restart } & \text { ITRANS } & \text { TLAPS } \\ \text { SS } & >0 & 0 & \text { NO } & & 0.0 \mathrm{~s} \\ \text { SS+TR } & >0 & 1 & \text { NO } & & 0.0 \mathrm{~s} \\ \text { TR } & 0 & 1 & \text { NO } & & 0.0 \mathrm{~s} \\ \text { SS } & >0 & 0 & \text { YES } & 0 & 0.0 \mathrm{~s} \\ \text { SS+TR } & >0 & 1 & \text { YES } & 0 & 0.0 \mathrm{~s} \\ \text { TR } & 0 & 1 & \text { YES } & 0 & 0.0 \mathrm{~s} \\ \text { TR } & 0 & 1 & \text { YES } & 0 & 0.0 \mathrm{~s} \\ \text { TR } & 0 & 1 & \text { YES } & 1 & \text { DTO } \\ \text { TR } & 0 & 1 & \text { YES } & 1 & \text { DTO }\end{array}$


calculation where the first logic argument is .FALSE. as well, and (3) the first logic argument is .FALSE. for an initial steady-state calculation. The second logic argument is not necessarily .FALSE. in the first situation when DTSTEP $=-99$ and TIMET $>0.0 \mathrm{~s}$ are input. To correct this, update FXTIME reprograms the logic test as IF ((IREST.NE.0) .AND.((ITRANS.EQ.1).OR.(STDYST.NE.0))) so that QINT is evaluated for the above three situations regardless of DSTEP $=-99$ and TIMET $>0.0 \mathrm{~s}$ being input in the first situation.

For the second error, the evaluation of DTDF in subroutine VLVEX to determine DELXMX = AMAX1(AMIN1(DFA*DTDFO, DFA*DTDF, DELXMX), DTMIN) (see Ref. 1) assumes the valve table has problem time as its independent variable. In general, this is not the case. A check valve, for example, generally has a valve table dependent on pressure or the pressure difference across the check-valve interface. DFA*DTDF defines the change in the valve table's independent variable that would determine the maximum change in the valve flow-area fraction during the next timestep. DFA*DTDF only can define DELXMX when the valve table's independent variable is problem time. The DFA*DTDF argument defining DELXMX has been eliminated, and DTDFO = DTO/AMAX1(ABS(FAVLVE-F), 1.0E-20) has been redefined by update FXTIME to be DTDF such that DTDF = DTO/AMAX1(ABS (FAVLVE-F), 1.0E-20), and DELXMX = AMAX1(AMIN1 (DFA*DTDF, DELXMX), DTMIN). F and FAVLVE are the valve flow-area fractions at the beginning and end of the previous DTO timestep.

\subsection{UPDATE FXTIME TESTING}

The W4LOOP and W4LOOPR standard test problems were reevaluated with update FXTIME in the manner described in section 2.0. Results of interest from the W4LOOP steady-state calculation and the W4LOOPR transient calculations with DSTEP $=-1$ or -99 TIMET $=0.0 \mathrm{~s}$ and DSTEP $=-99$ and TIMET $=0.0,0.0001,0.01,1.0$, 100.0 , or $10000.0 \mathrm{~s}$ are shown in Appendix B. Changes to the input-data TRACIN files and very small remaining differences from the DSTEP $=-1$ case terminal output are shown in bold type. DIFF differences between TRCOUT files are shown or are commented on if there is an extensive difference. Now the opening of VALVE 6, simulating a cold-leg large break, is done the same in all seven cases. Most of the difference in results among cases (due to a difference in valve opening during the first timestep because of TIMET $=0.0 \mathrm{~s}$ or $>0.0 \mathrm{~s}$ being input) has been eliminated. Now no shift is done in the ROD-140 power-table, absicssa-coordinate values during the first timestep.

The cause of the remaining small difference in some of the output values ( $\leq 4$ th significant digit for TIMET $\leq 100.0 \mathrm{~s}$ and $\leq$ 3rd significant digit for TIMET $=10000.0 \mathrm{~s}$ ) has not been determined. With solution differences caused solely by inputting different values of TIMET, all applications of TIMET and the variables it defines (ETIME, STIME, STIMET, TMMAX, DMPDT, TMSTNU, TMTLD, TABTIM, TABLE (NINT2+1), TIMIN, A(LCNTL+IA(LCNTL)-1), TEDIT, TSEDIT, TGRAF, TDUMP, $\mathrm{A}(\mathrm{KPT}+6), \mathrm{A}(\mathrm{KPT}+7)$, TLAPS, and TOLD) were examined for their having an effect on the solution. No cause could be found except for the first additional error noted above. 
When debugging TRAC-P in the future, the programmer should consider that the remaining difference may be due to missing code. For example, additional variables from a data dump that should be time shifted by $\Delta t_{d m p}$, DMPDT = TIMET - DMPTIM $=$ restart time - data-dump time, for the restart calculation are not being time shifted. For TIMET $=0.0 \mathrm{~s}$ and DMPTIM $=0.0 \mathrm{~s}$ from the last data dump of a steadystate calculation, $\Delta \mathrm{t}_{\mathrm{dmp}}=0.0 \mathrm{~s}$. Not applying a $\Delta \mathrm{t}_{\mathrm{dmp}}=0.0 \mathrm{~s}$ time shift to some variables would have no effect on the solution, but not applying a $\Delta \mathrm{t}_{\mathrm{dmp}}>0.0 \mathrm{~s}$ time shift because TIMET $>0.0 \mathrm{~s}$ would affect the solution.

Trouble Report 238 has been created to document this remaining error so that it can be investigated at a later time.

\subsection{FEATURE DOCUMENTATION}

The DSTEP $=-99$ and TIMET $\geq 0.0 \mathrm{~s}$ feature in TRAC-P has not been documented. It can be documented appropriately by making the following change to the Main-Data Card 3 descriptions of input-data variables DSTEP and TIMET in Chapter 6 of the TRAC-P Users Guide.

Main-Data Card 3. (Format I14, E14.4) DSTEP, TIMET

Columns Variable Description

1-14 DSTEP Timestep number of the TRCDMP-file data dump to be read from the TRCRST file for a restart calculation. If DSTEP $<0$, the last data dump found will be used. Input DSTEP $=-99$ and TIMET $\geq 0.0 \mathrm{~s}$ to define TIMET to be the calculation start time for the last data-dump restart calculation. Input DSTEP $=0$ for an initial calculation where all the input data is defined by the TRACIN file.

15-28 TIMET Calculation start time (s). If DSTEP < 0 (but not -99) or TIMET $<0.0 \mathrm{~s}$, the time obtained from the retrieved data dump overrides the TIMET input-data value.

\subsection{CONCLUSIONS}

The DSTEP $=-99$ and TIMET $\geq 0.0 \mathrm{~s}$ features in TRAC-P Version 5.4.28 have been tested on the W4LOOP and W4LOOPR standard test problems, which have relative independent-variable component-action tables. The W4LOOPR solutions were different for different values of TIMET when the solutions should have been the same. Two coding errors that contribute to that difference and one unrelated coding error have been corrected by update FXTIME. With update FXTIME and other pending updates (FXJLPAR, FXKILL, CLSUNIT, FXLOOP, FXTPTM, SUMNMULN, FXFILL, FXGRAV, ZERORGH, and DTPCON) in TRAC-P Version 5.4.28, the same cases have lesser differences in the output values ( $\leq 4$ th significant digit for TIMET $\leq 100.0 \mathrm{~s}$ and $\leq 3 \mathrm{rd}$ significant digit for TIMET $=10000.0 \mathrm{~s}$ ). Further debugging of this feature in TRAC-P is needed. Trouble Report 238 has been created to document this remaining error in the DSTEP $=-99$ and TIMET $\geq 0.0 \mathrm{~s}$ feature of TRAC-P. 


\section{ACKNOWLEDGMENT}

The author wishes to thank Richard J. Smith for valuable discussions during the development and testing of this TRAC-P update.

\subsection{REFERENCE}

1. P. T. Giguere, "Improved Timestep-Size Diagnostic Edits For TRAC-P," LA-UR96-1502 (April 1996). 


\section{Appendix A \\ Listing of Update FXTIME}

\section{Update FXTIME}

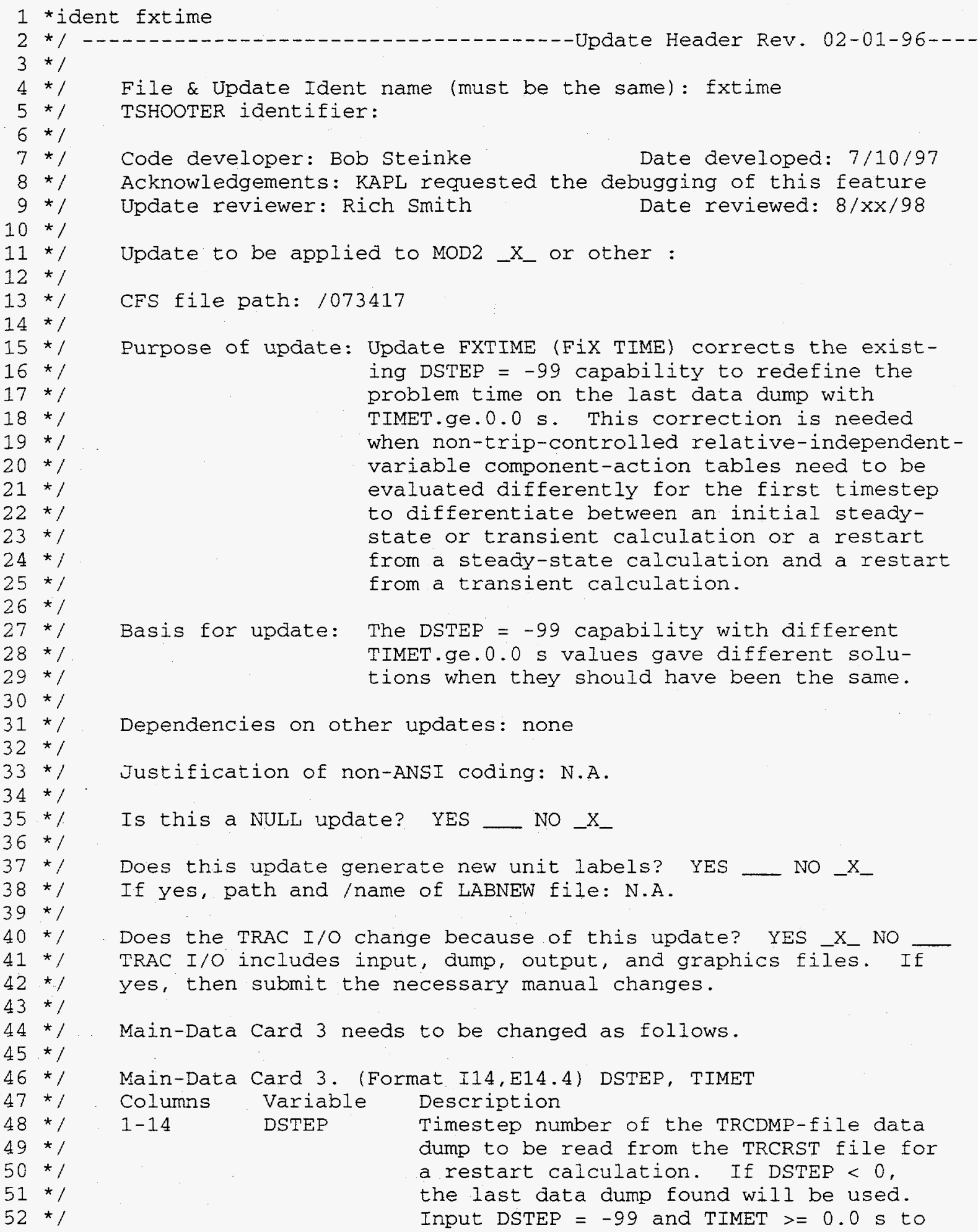




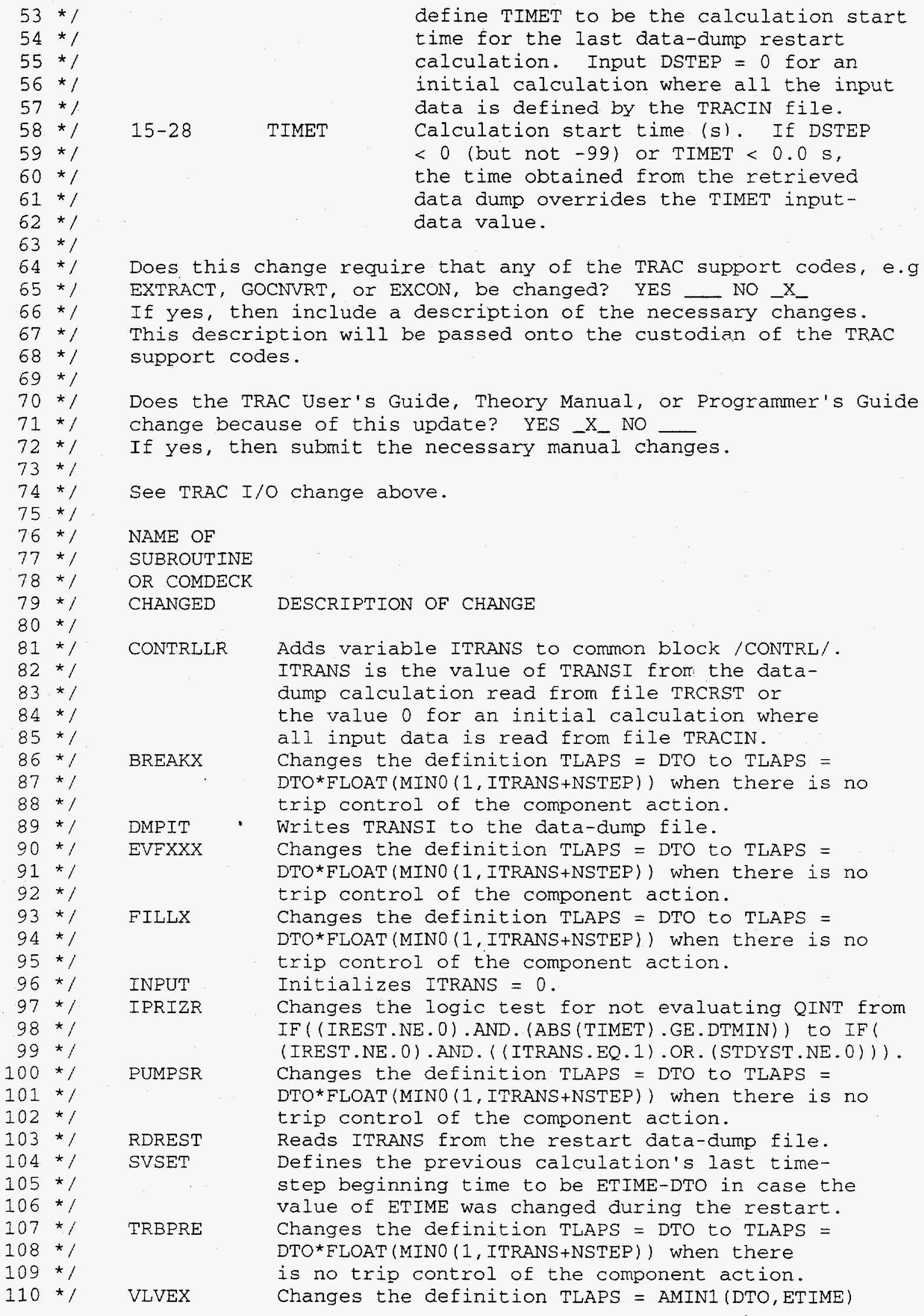




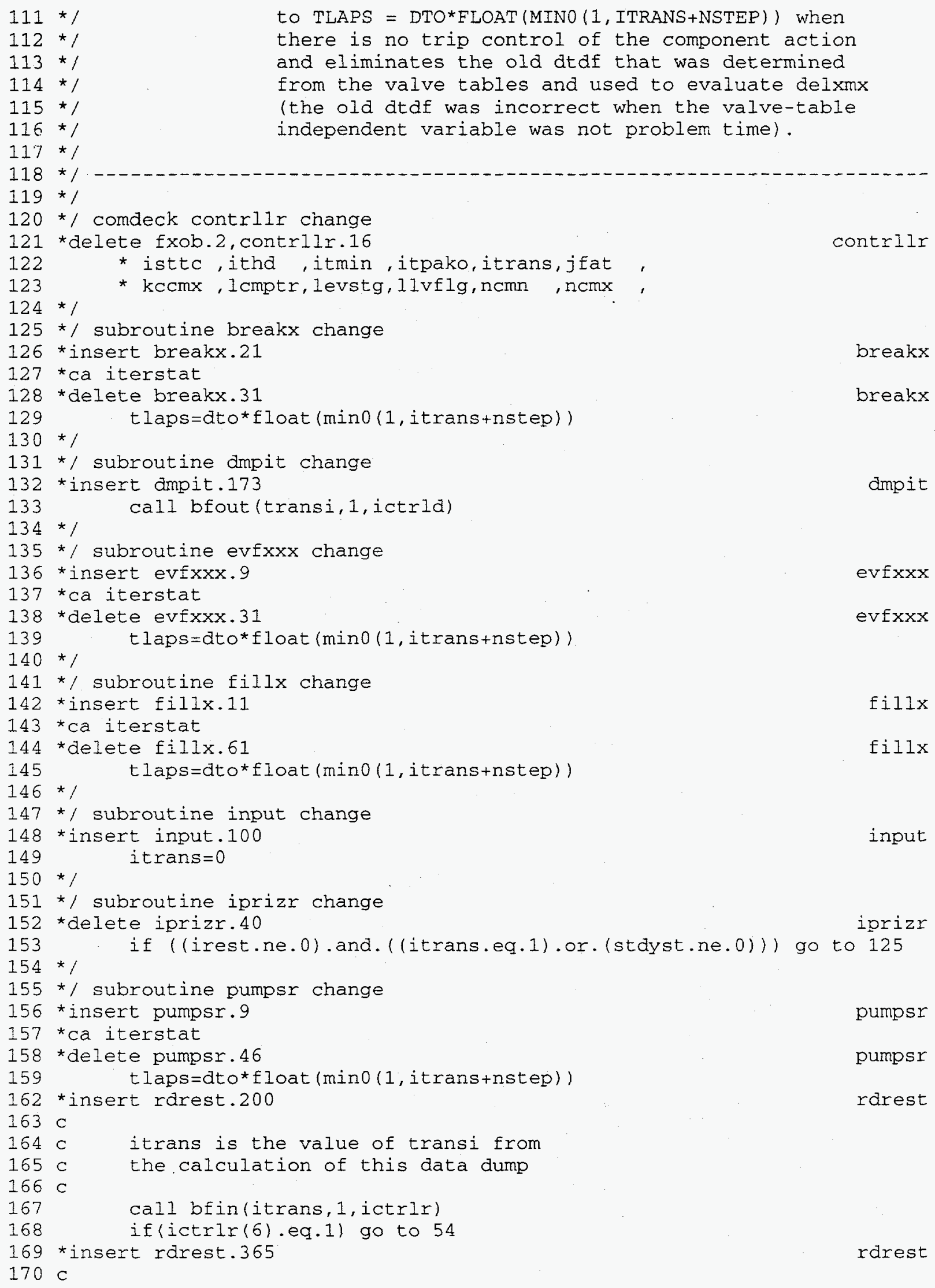




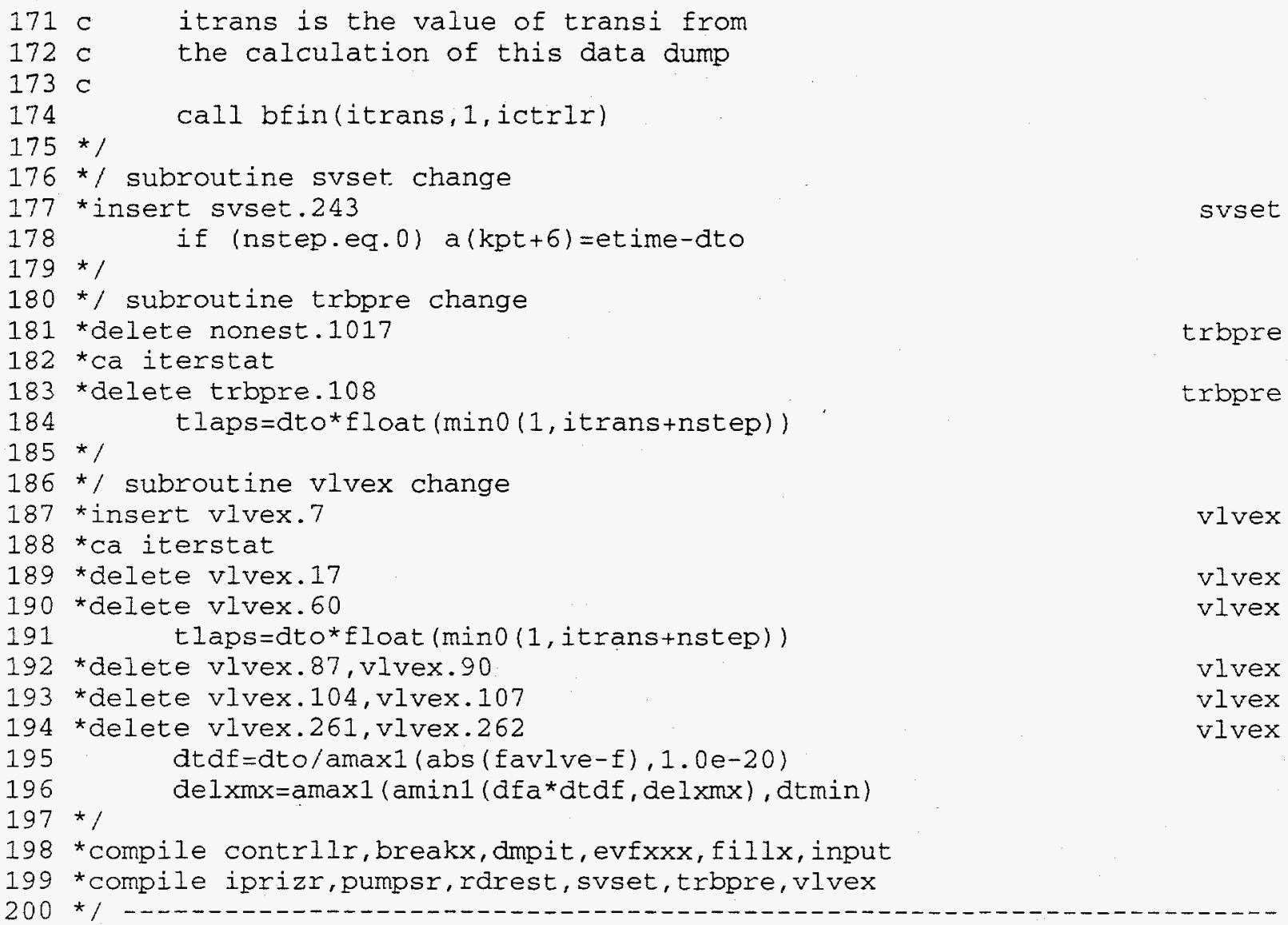




\section{Appendix B \\ W4LOOP and W4LOOPR Test-Problem Modified Input-Data and Terminal Output Listings and TRCOUT-File Comparisons to DSTEP $=-1$ and TIMET $=0.0 \mathrm{~s}$ for DSTEP $=-99$ and TIMET $=0.0 \mathrm{~s}, 0.0001 \mathrm{~s}, 0.01 \mathrm{~s}, 1.0 \mathrm{~s}, 100.0 \mathrm{~s}$, and $10000.0 \mathrm{~s}$}

W4LOOP file with NRPWTB $=-20$ for ROD 140

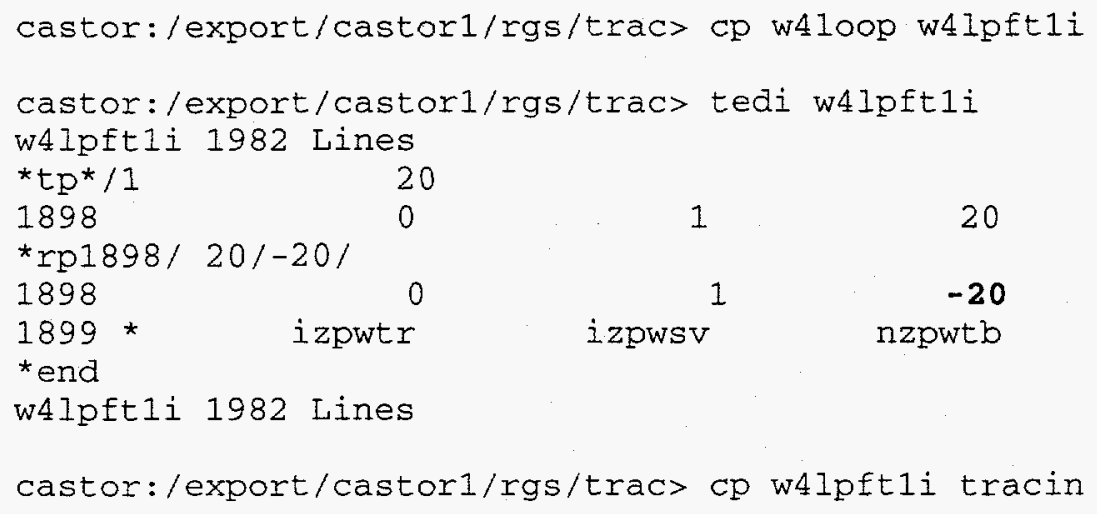




$\begin{array}{ccccccc}\text { time } & \text { time } & \text { domain } & \text { edit } & \text { edit } & \text { edit } & \text { edit } \\ \text { step (s) } & \text { step (s) } & \text { end (s) } & \text { step (s) } & \text { step (s) } & \text { step (s) step (s) } \\ 5.000 \mathrm{E}-02 & 2.000 \mathrm{E}+00 & 5.000 \mathrm{E}+01 & 4.400 \mathrm{E}+01 & 1.000 \mathrm{E}+00 & 4.400 \mathrm{E}+01 & 4.400 \mathrm{E}+01\end{array}$

steady-state calculation heat-transfer/hydraulic time-step ratio is $1.0000 \mathrm{E}+01$ convective energy-error controller is $3.4121 \mathrm{E}+20 \mathrm{btu} / \mathrm{hr}$

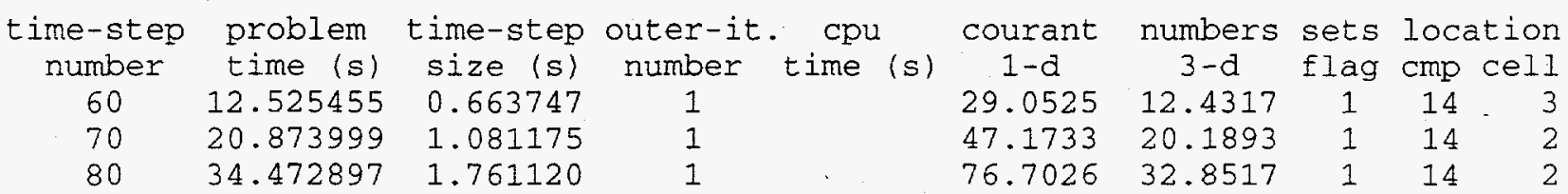

\begin{tabular}{|c|c|c|c|c|c|c|}
\hline & & tim & ta $t$ & 0 be & & \\
\hline $\begin{array}{l}\text { minimum } \\
\text { time }\end{array}$ & $\begin{array}{l}\text { maximum } \\
\text { time }\end{array}$ & $\begin{array}{l}\text { time } \\
\text { domain }\end{array}$ & $\begin{array}{l}\text { long } \\
\text { edit }\end{array}$ & $\begin{array}{l}\text { graphics } \\
\text { edit }\end{array}$ & $\begin{array}{l}\text { dump } \\
\text { edit }\end{array}$ & $\begin{array}{l}\text { short } \\
\text { edit }\end{array}$ \\
\hline & . & end (s) & step (s) & step (s) & ep (s) & (s) \\
\hline
\end{tabular}

steady-state calculation heat-transfer/hydraulic time-step ratio is $1.0000 \mathrm{E}+01$ convective energy-error controller is $3.4121 \mathrm{E}+20 \mathrm{btu} / \mathrm{hr}$

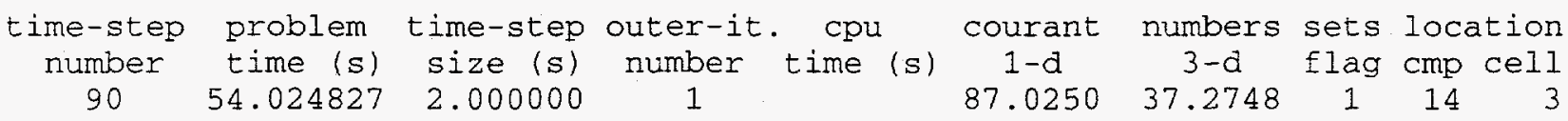

generalized steady-state convergence-test results

problem time is $\quad 74.024827 \mathrm{~s}$ and time-step size is $2.000000 \mathrm{~s}$ time-step number is 100 and number of outer iterations is 1

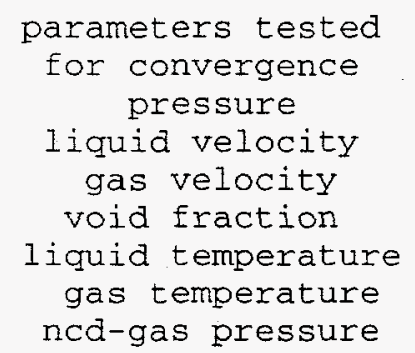

max.fr.change per second
over last time step
-0.000002
0.002995
-0.001235
0.000222
0.000198
0.000000
0.000000

cell number number

10

10

27

27

10

27

21

2
3
4
3
1
2
1

constrained steady-state calculation parameters

\begin{tabular}{|c|c|c|c|c|c|c|}
\hline comp & $\begin{array}{l}\text { hent } \\
\text { dmber }\end{array}$ & $\begin{array}{c}\text { minimum } \\
\text { value }\end{array}$ & $\begin{array}{l}\text { adjusted } \\
\text { parameter }\end{array}$ & $\begin{array}{l}\text { maximum } \\
\text { value }\end{array}$ & $\begin{array}{l}\text { monitored } \\
\text { parameter }\end{array}$ & $\begin{array}{c}\text { desired } \\
\text { value }\end{array}$ \\
\hline$m$ & 1 & $E+00$ & $1.13527 \mathrm{E}+03$ & $90986 E+03$ & Patcis & $5 E+07$ \\
\hline & & $r$ & rpm & $r$ & hr & $\mathrm{n} / \mathrm{hr}$ \\
\hline ump & 13 & $0000 E+00$ & $1.13994 \mathrm{E}+03$ & $90986 E+C$ & .012 & 012 \\
\hline & & & & & & hr \\
\hline 1 & 8 & 0 & & 7 & 6 & 06 \\
\hline & & & & & & \\
\hline fill & 23 & 0 & 6 & 8 & 6 & .3790 \\
\hline & & & & & & \\
\hline 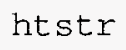 & 126 & 8.0000 & +00 & +00 & 02 & 02 \\
\hline & & & & & & \\
\hline 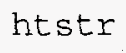 & 127 & $8.00000 \mathrm{E}-01$ & $1.12180 \mathrm{E}+00$ & $1.25000 E+00$ & $5.30470 \mathrm{E}+02$ & $5.30330 \mathrm{E}+02$ \\
\hline$-\infty$ & & $000 \mathrm{E}-01$ & $.12130 \mathrm{E}+00$ & $1.25000 E+00$ & $5.30467 E+02$ & $E+02$ \\
\hline
\end{tabular}




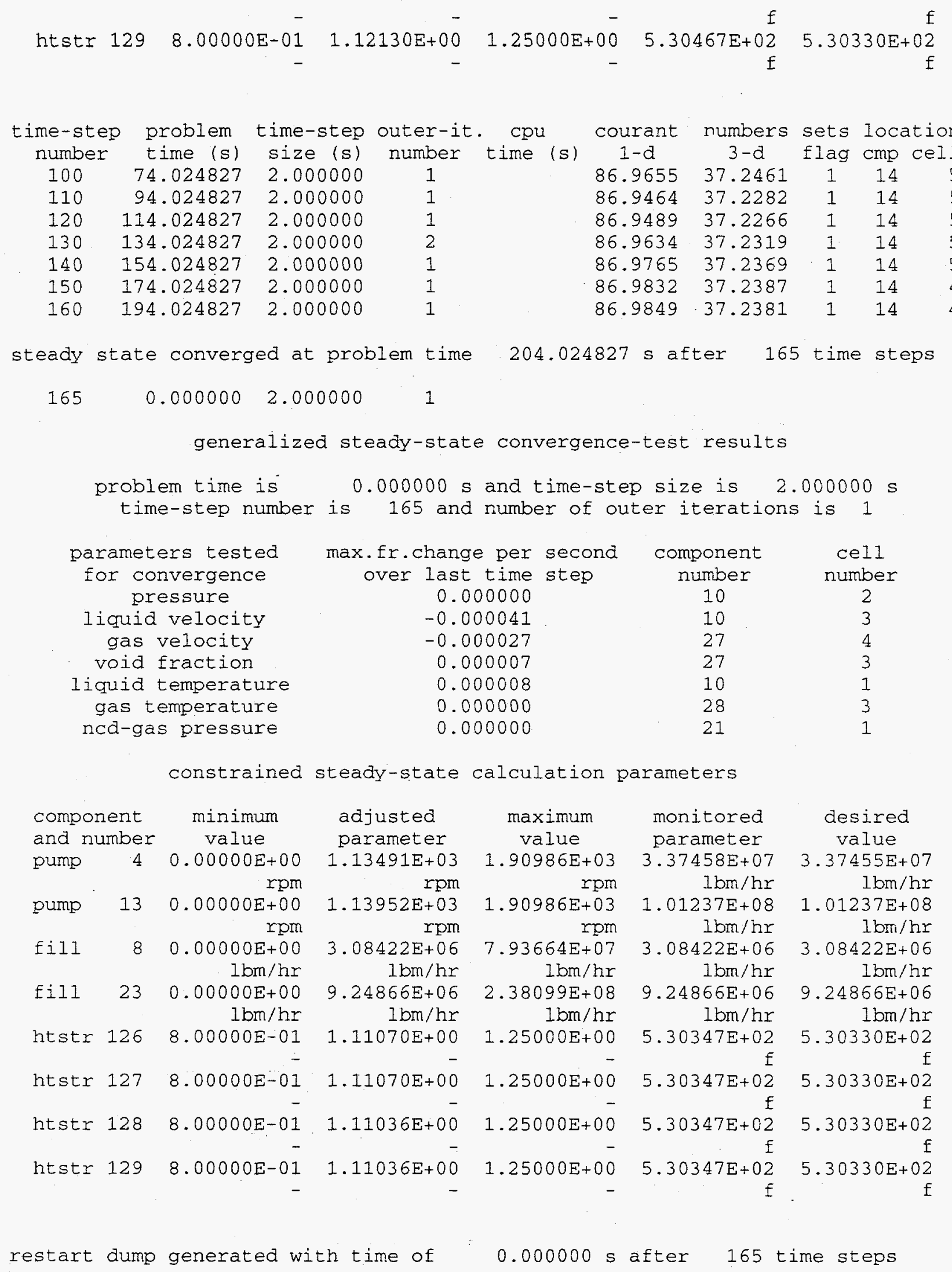




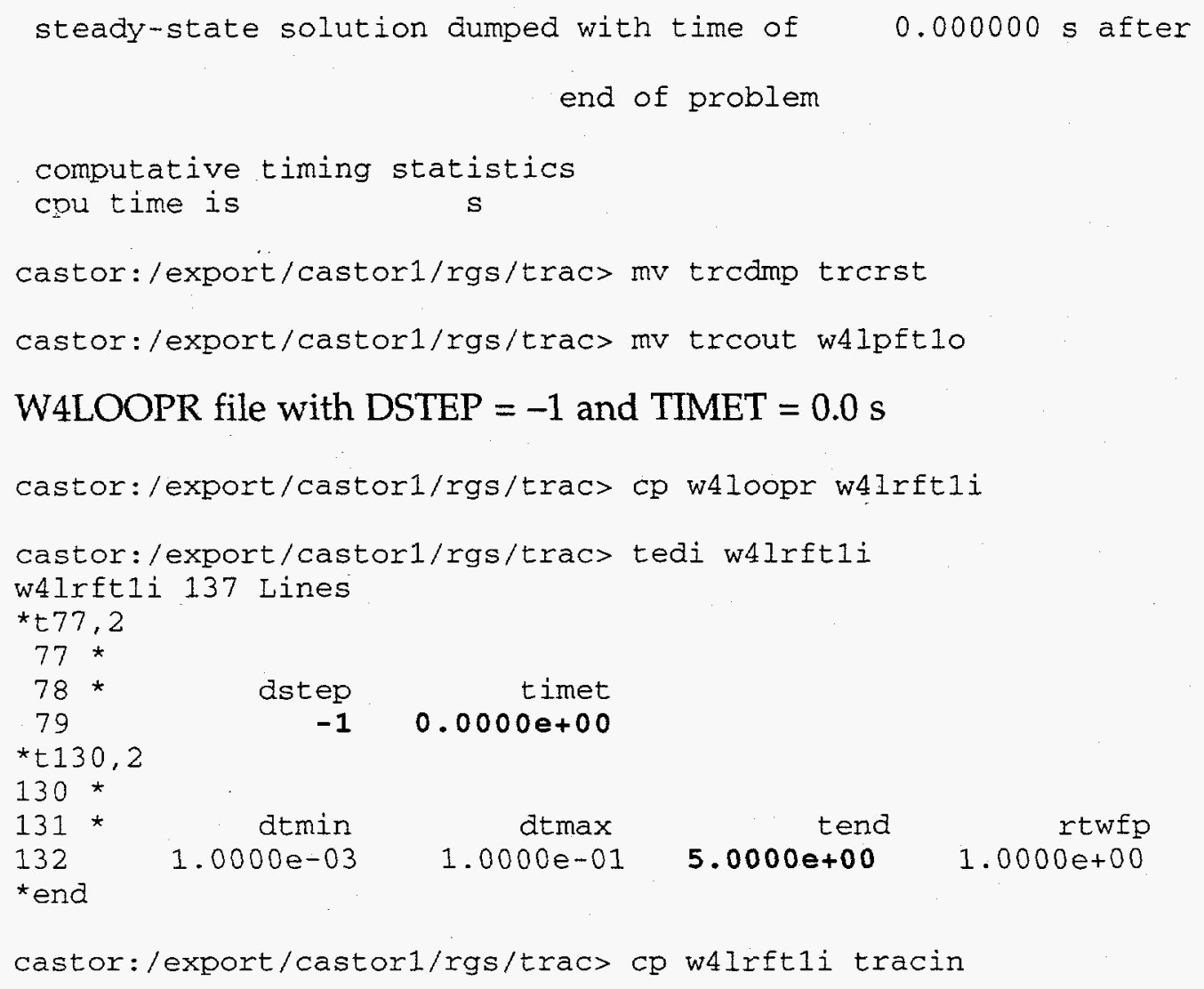




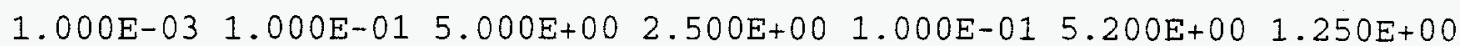
convective energy-error controller is $3.4121 \mathrm{E}+20 \mathrm{btu} / \mathrm{hr}$

\begin{tabular}{|c|c|c|c|c|c|c|c|c|c|}
\hline $\begin{array}{c}\text { me-step } \\
\text { number } \\
0 \\
1\end{array}$ & $\begin{array}{l}\text { problem } \\
\text { time (s) } \\
0.000000 \\
0.010000\end{array}$ & $\begin{array}{l}\text { time-step } \\
\text { size (s) } \\
0.010000 \\
0.010000\end{array}$ & $\begin{array}{c}\text { uter-it. } \\
\text { number } \\
1 \\
1\end{array}$ & $\begin{array}{l}\text { cpu } \\
\text { time (s) }\end{array}$ & $\begin{array}{c}\text { courant } \\
1-d \\
0.4349\end{array}$ & $\begin{array}{c}\text { numbers } \\
3-d \\
0.1862\end{array}$ & $\begin{array}{c}\text { sets } \\
\text { flag } \\
1\end{array}$ & $\begin{array}{l}10 \mathrm{ca} \\
\mathrm{cmp} \\
14\end{array}$ & $\begin{array}{l}\text { ion } \\
\text { ell }\end{array}$ \\
\hline $\begin{array}{l}\text { me-step } \\
\text { number } \\
2\end{array}$ & $\begin{array}{l}\text { problem } \\
\text { time (s) } \\
0.020500\end{array}$ & $\begin{array}{l}\text { time-step } \\
\text { size (s) } \\
0.010500\end{array}$ & $\begin{array}{c}\text { outer-it. } \\
\text { number } \\
2\end{array}$ & $\begin{array}{l}\text { cpu } \\
\text { time (s) }\end{array}$ & $\underset{1-d}{\text { courant }}$ & $\begin{array}{c}\text { numbers } \\
3-d\end{array}$ & $\begin{array}{l}\text { sets } \\
\text { flag }\end{array}$ & 10 & 11 \\
\hline $\begin{array}{c}\text { me-step } \\
\text { number } \\
3\end{array}$ & $\begin{array}{l}\text { problem } \\
\text { time (s) } \\
0.030251\end{array}$ & $\begin{array}{l}\text { time-step } \\
\text { size (s) } \\
0.009751\end{array}$ & $\begin{array}{c}\text { outer-it. } \\
\text { number } \\
2\end{array}$ & - cpu & $\begin{array}{c}\text { cour } \\
\cdot 1-c\end{array}$ & $\begin{array}{c}\text { numbers } \\
3-d\end{array}$ & $\begin{array}{l}\text { sets } \\
\text { flag }\end{array}$ & & \\
\hline $\begin{array}{c}\text { ime-step } \\
\text { number } \\
4\end{array}$ & $\begin{array}{l}\text { problem } \\
\text { time (s) } \\
0.038952\end{array}$ & $\begin{array}{l}\text { time-step } \\
\text { size (s) } \\
0.008701\end{array}$ & $\begin{array}{c}\text { outer-it. } \\
\text { number } \\
2\end{array}$ & time (s) & $\begin{array}{c}\text { courant } \\
1-d\end{array}$ & $\begin{array}{c}\text { numbers } \\
3-d\end{array}$ & $\begin{array}{l}\text { sets } \\
\text { flag }\end{array}$ & $\begin{array}{r}10 \mathrm{ca} \\
\mathrm{cmp} \mathrm{c}\end{array}$ & \\
\hline $\begin{array}{l}\text { ime-step } \\
\text { number } \\
5\end{array}$ & $\begin{array}{l}\text { problem } \\
\text { time (s) } \\
0.046678\end{array}$ & $\begin{array}{r}\text { time } \\
\text { siz } \\
0.0\end{array}$ & $\begin{array}{c}\text { outer-it. } \\
\text { number } \\
2\end{array}$ & ${ }_{\text {time }}^{c p u}(s)$ & $\begin{array}{c}\text { courant } \\
1-d\end{array}$ & $\begin{array}{l}\text { numbers } \\
3-d\end{array}$ & $\begin{array}{l}\text { sets } \\
\text { flag }\end{array}$ & $\begin{array}{l}\text { loca } \\
\text { cmp } \mathrm{C}\end{array}$ & \\
\hline $\begin{array}{c}\text { ime-step } \\
\text { number } \\
10 \\
20 \\
30 \\
40 \\
50 \\
60 \\
70 \\
80 \\
90 \\
100 \\
110 \\
117 \\
120 \\
130 \\
140 \\
150 \\
160 \\
165\end{array}$ & $\begin{array}{l}\text { problem } \\
\text { time (s) } \\
0.074053 \\
0.097389 \\
0.108684 \\
0.126382 \\
0.155211 \\
0.202170 \\
0.278661 \\
0.403257 \\
0.606212 \\
0.877810 \\
1.136038 \\
1.316212 \\
1.392960 \\
1.649910 \\
1.909170 \\
2.170021 \\
2.433681 \\
2.565866\end{array}$ & $\begin{array}{c}\text { tim } \\
\text { si } \\
0 . \\
0 . \\
0 . \\
0 . \\
0 . \\
0 . \\
0 . \\
0 .\end{array}$ & $\begin{array}{c}\text { outer-it. } \\
\text { number } \\
2 \\
2 \\
2 \\
2 \\
2 \\
2 \\
2 \\
2 \\
2 \\
2 \\
2 \\
2 \\
2 \\
2 \\
2 \\
3 \\
2 \\
2\end{array}$ & time (s) & $\begin{array}{c}\text { courant } \\
1-d \\
8.9651 \\
1.8388 \\
67.2486 \\
67.7338 \\
156.1533 \\
276.7920 \\
334.2688 \\
447.5118 \\
846.8229 \\
013.5059 \\
002.7750\end{array}$ & $\begin{array}{l}\text { umbers } \\
3-d \\
0.1016 \\
0.0437 \\
0.0568 \\
0.0967 \\
0.1509 \\
0.2368 \\
0.3822 \\
0.6108 \\
0.9792 \\
0.9799 \\
0.9348\end{array}$ & $\begin{array}{c}\text { sets } \\
\text { flag } \\
1 \\
1 \\
1 \\
1 \\
1 \\
1 \\
1 \\
1 \\
1 \\
1 \\
1 \\
1\end{array}$ & loca & t \\
\hline $\begin{array}{l}220 \\
230 \\
240 \\
250\end{array}$ & $\begin{array}{l}\text { problem } \\
\text { time (s) } \\
2.697301 \\
2.959375 \\
3.219994 \\
3.479769 \\
3.739053 \\
3.816714 \\
3.997667 \\
4.255754 \\
4.513512 \\
4.771465\end{array}$ & $\begin{array}{l}\text { Eime-step } \\
\text { size (s) } \\
0.026182 \\
0.026168 \\
0.025966 \\
0.025949 \\
0.025913 \\
0.025887 \\
0.025820 \\
0.025754 \\
0.026253 \\
0.025141\end{array}$ & $\begin{array}{l}\text { er-it } \\
\text { mber } \\
2 \\
2 \\
2 \\
2 \\
2 \\
2 \\
2 \\
2 \\
2 \\
2\end{array}$ & $\begin{array}{c}\text { cpu } \\
\text { time }\end{array}$ & $\begin{array}{c}\text { courant } \\
1-d \\
995.7142 \\
998.6537 \\
997.6081 \\
998.5224 \\
001.0128\end{array}$ & $\begin{array}{l}\text { numbers } \\
\begin{array}{c}3-\mathrm{d} \\
0.7753 \\
0.7363 \\
0.6909 \\
0.6543 \\
0.6408\end{array}\end{array}$ & $\begin{array}{c}\text { sets } \\
\text { flag } \\
1 \\
1 \\
1 \\
1 \\
1\end{array}$ & $\begin{array}{l}\text { loca } \\
\text { cmp }\end{array}$ & \\
\hline
\end{tabular}


restart dump generated at problem time $5.021983 \mathrm{~s}$ after 260 time steps

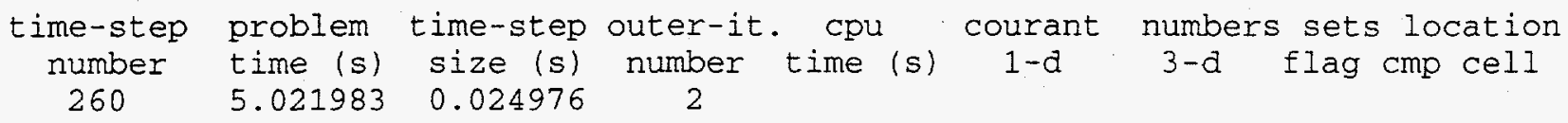

end of problem

computative timing statistics

cpu time is

$s$

castor:/export/castorl/rgs/trac> mv trcout w4Irftlo

W4LOOPR file with DSTEP $=-99$ and TIMET $=0.0 \mathrm{~s}$

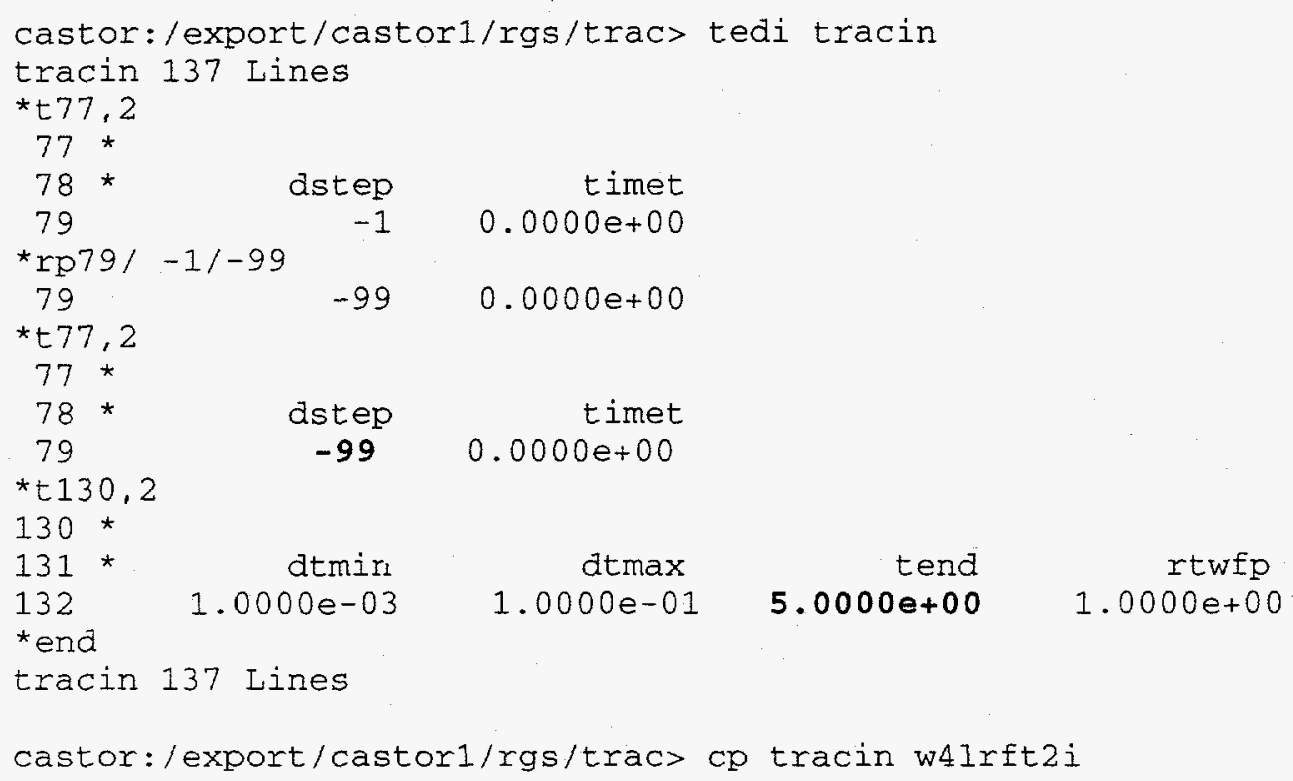

W4LOOPR terminal output based on DSTEP $=-99$ and TIMET $=0.0 \mathrm{~s}$ castor:/export/castor1/rgs/trac> trac

transient reactor analysis code

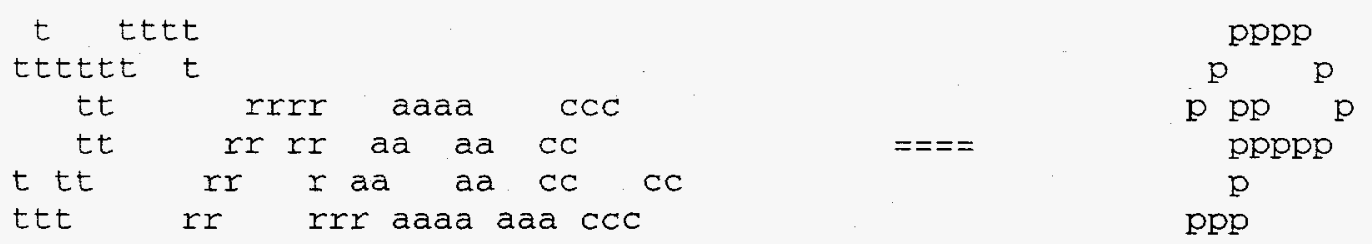

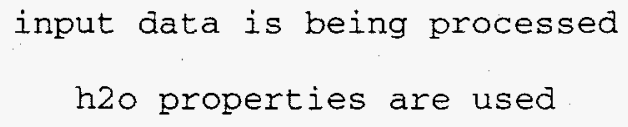

restarting from final dump found at time-step number 165 and time $0.00000 \mathrm{E}+00 \mathrm{~s}$ 
restarting time reset to $0.00000 \mathrm{E}+00 \mathrm{~s}$

restart dump generated at problem time

0.000000 s after

0 time steps

\begin{tabular}{|c|c|c|c|c|c|c|}
\hline num & $\begin{array}{c}\text { maximum } \\
\text { time }\end{array}$ & $\begin{array}{l}\text { time } \\
\text { domain }\end{array}$ & $\begin{array}{l}\text { long } \\
\text { edit }\end{array}$ & $\begin{array}{l}\text { graphics } \\
\text { edit }\end{array}$ & $\begin{array}{l}\text { dump } \\
\text { edit }\end{array}$ & $\begin{array}{l}\text { short } \\
\text { edit }\end{array}$ \\
\hline & 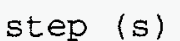 & end (s) & ster & step (s) & step (s) & st \\
\hline
\end{tabular}

1.000E-03 1.000E-01 5.000E+00 2.500E+00 1.000E-01 5.200E+00 1.250E+00 convective energy-error controller is $3.4121 \mathrm{E}+20 \mathrm{btu} / \mathrm{hr}$

\begin{tabular}{|c|c|c|c|c|c|c|c|c|}
\hline time-step & problem & time-step & outer-it & cpu & courant & numbers & sets & 100 \\
\hline mber & time (s) & size (s) & number & time (s) & $1-d$ & $3-d$ & flag & $\mathrm{cm}$ \\
\hline 0 & 0.000000 & 0.010000 & 1 & & 0.4349 & 0.1862 & 1 & 14 \\
\hline 1 & 0.010000 & 0.010000 & 1 & & & & & \\
\hline
\end{tabular}
time-step problem time-step outer-it. cpu courant numbers sets location number time (s) size (s) number time (s) $1-d$ 3-d flag cmp cell $20.020500 \quad 0.010500 \quad 2$

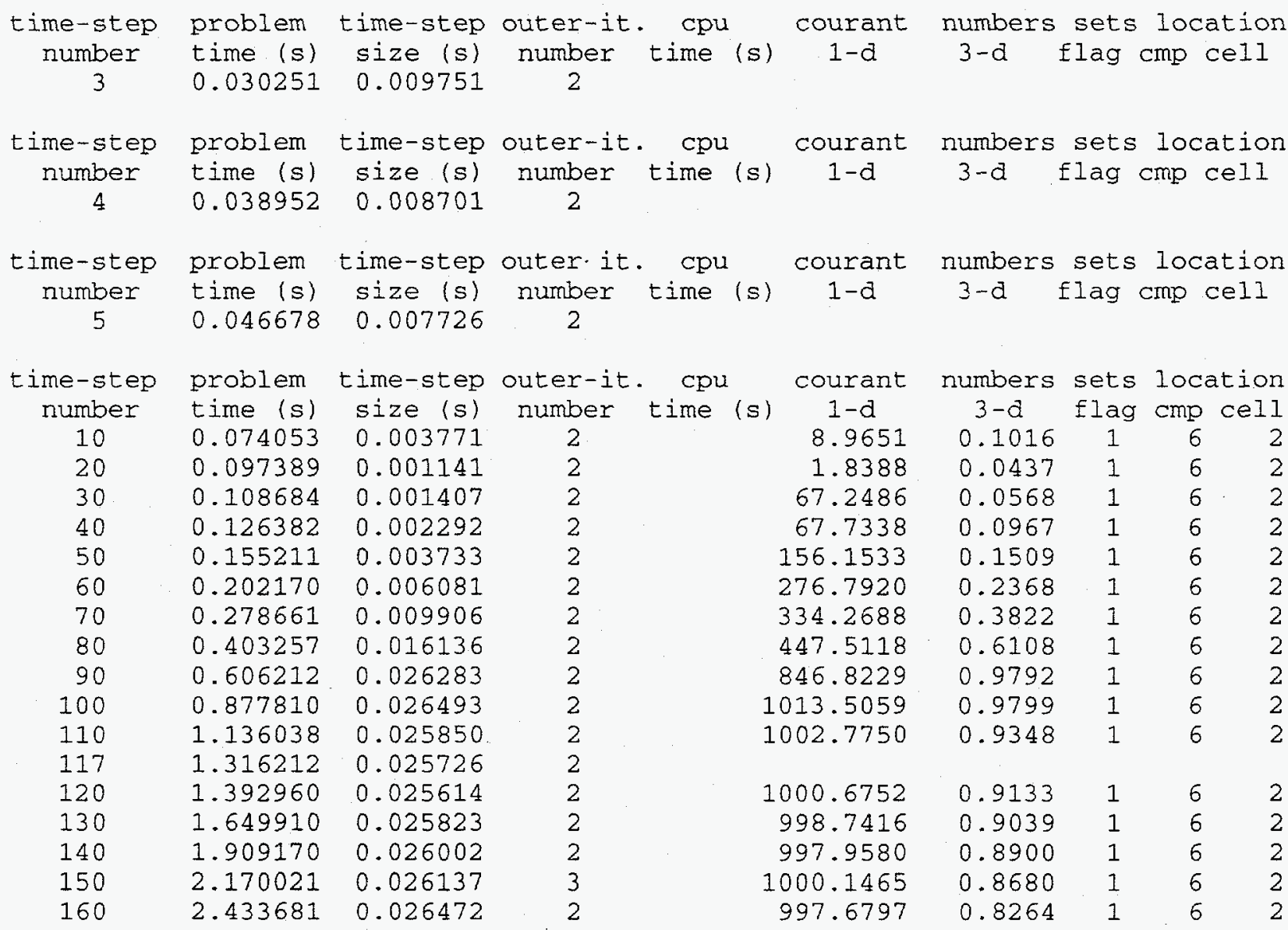

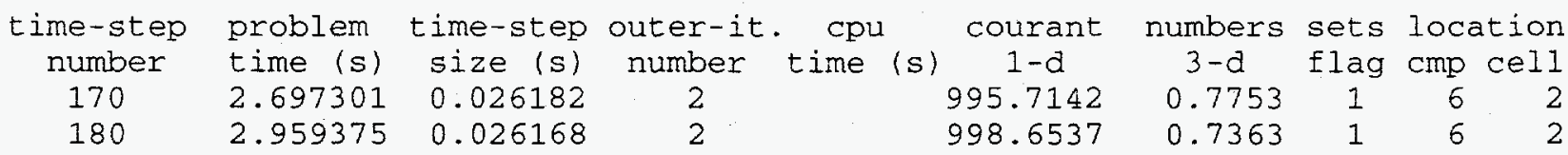




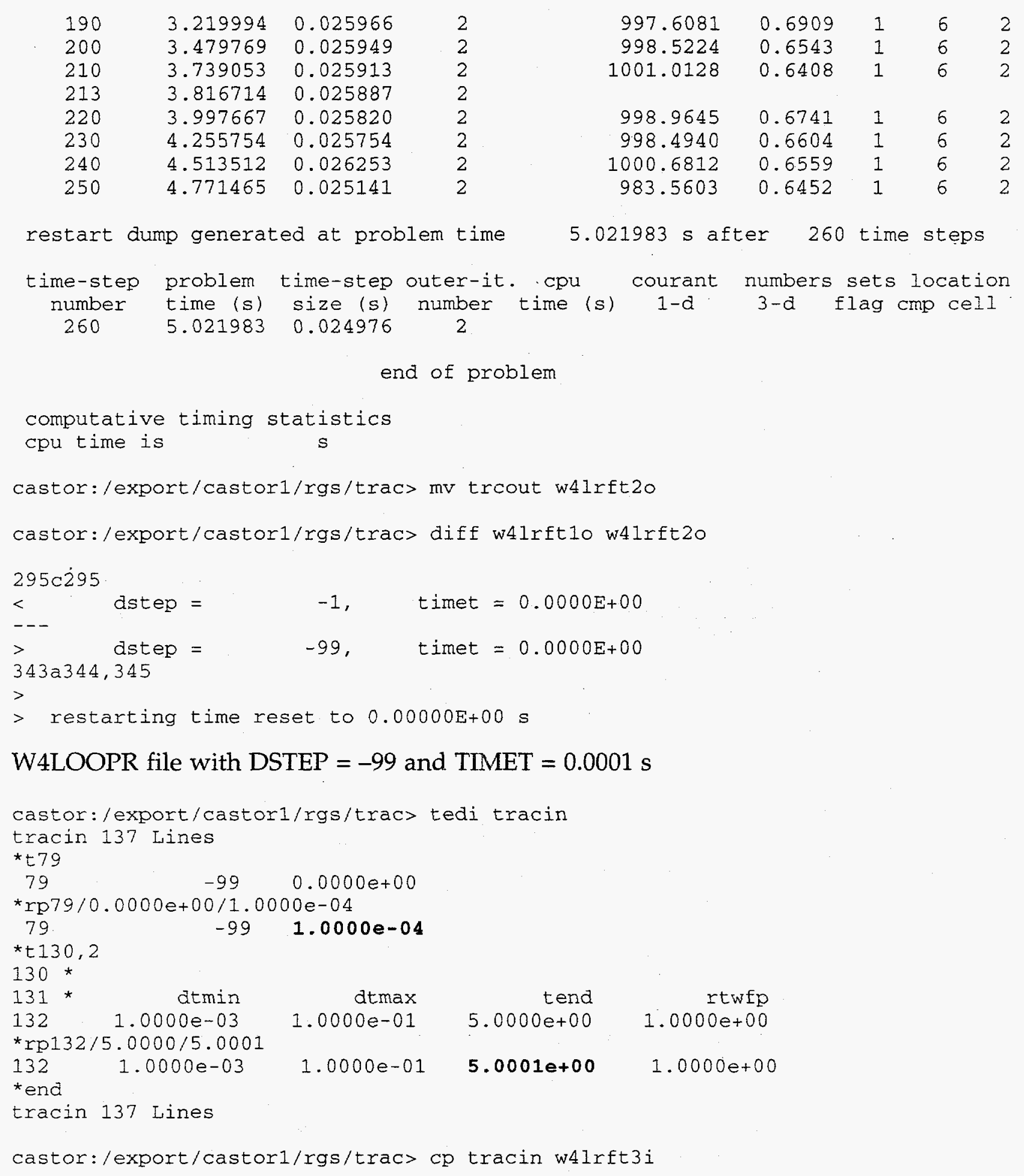




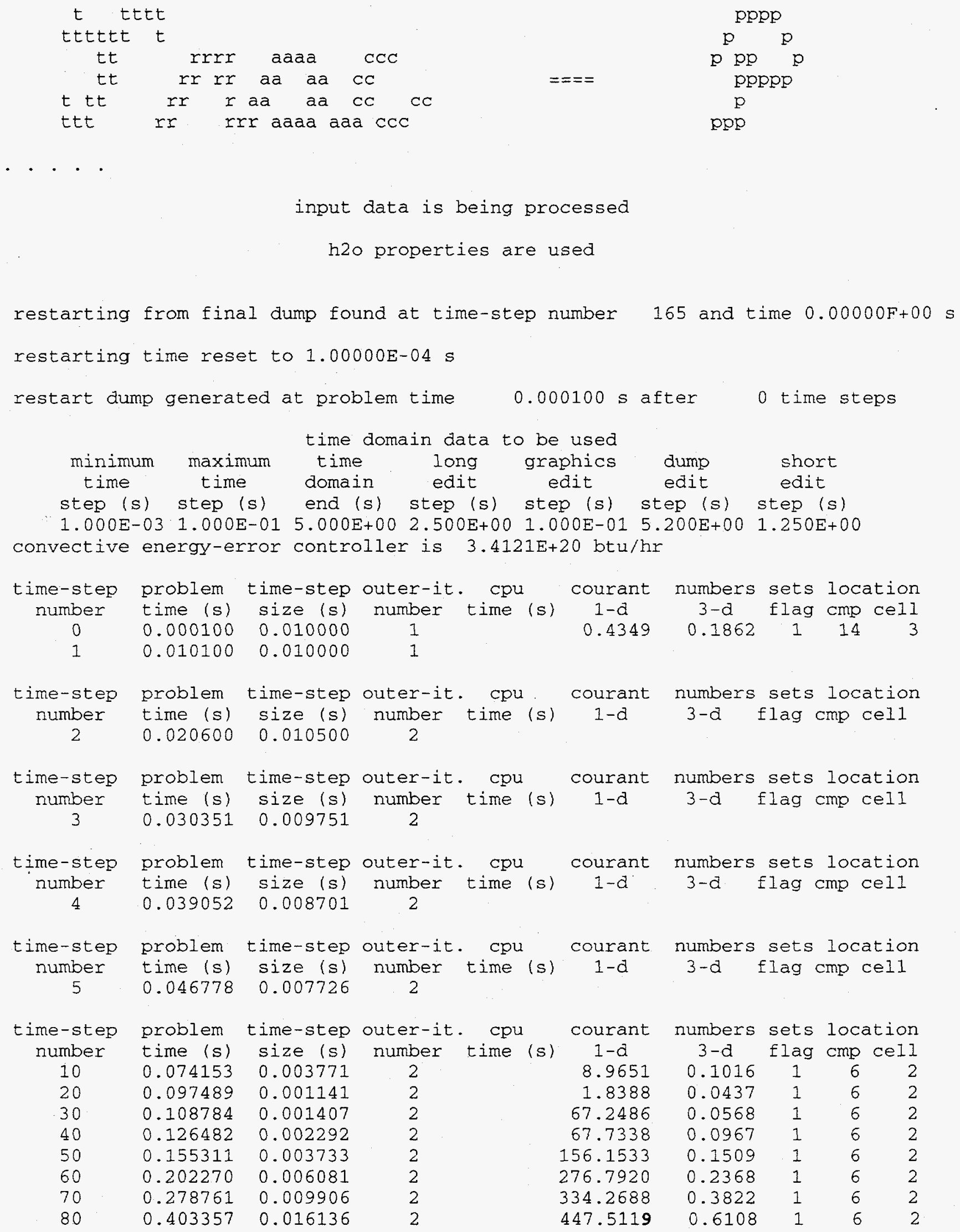




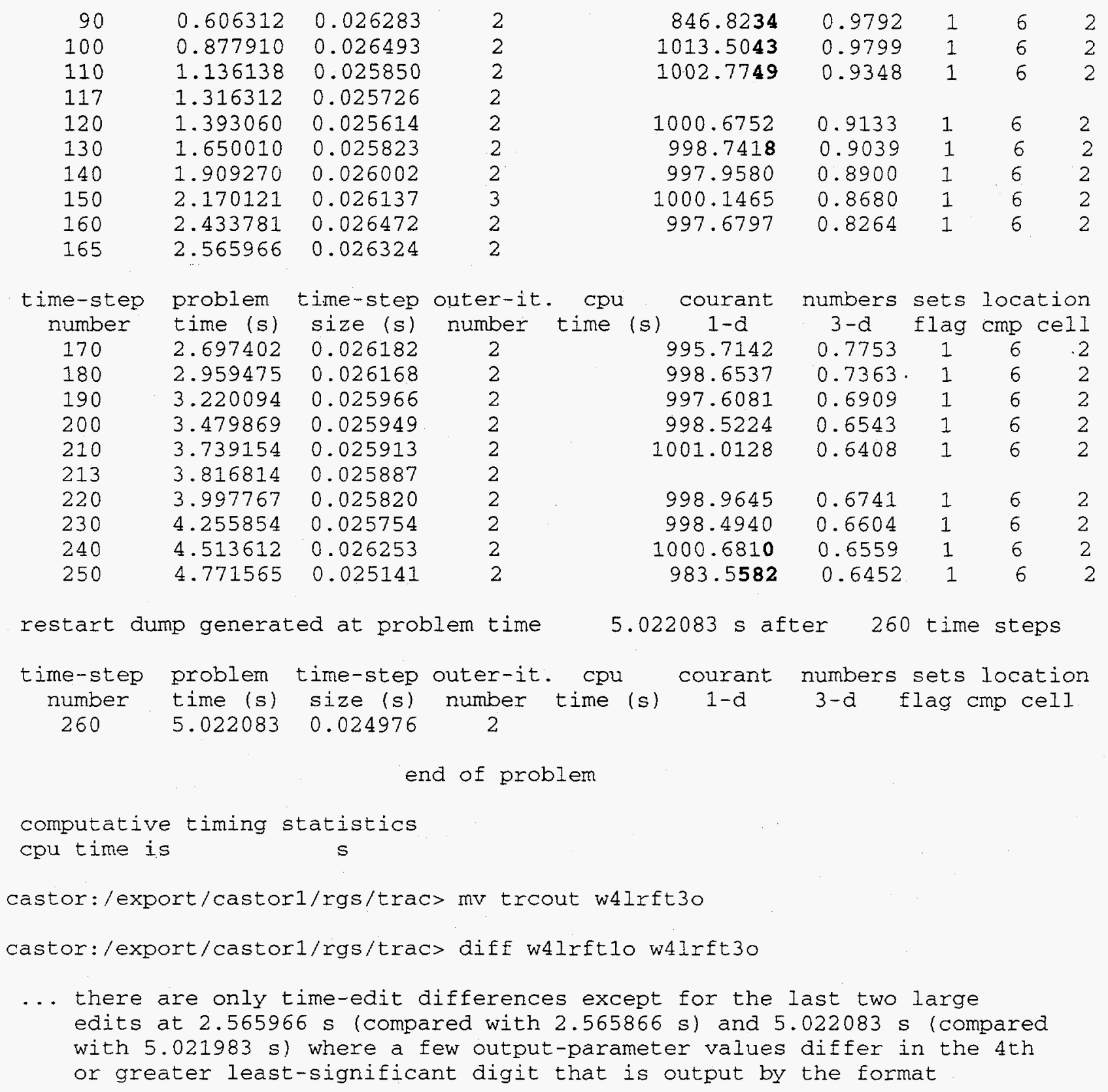

\section{W4LOOPR file with DSTEP $=-99$ and TIMET $=0.01 \mathrm{~s}$}

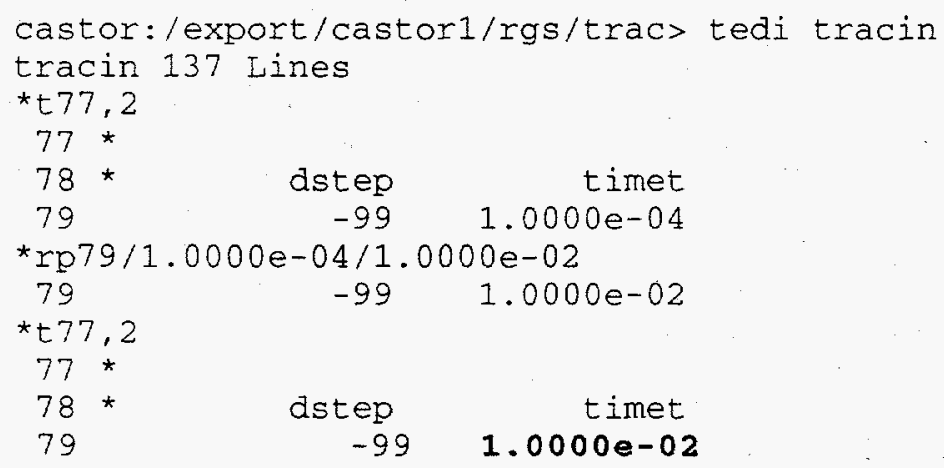




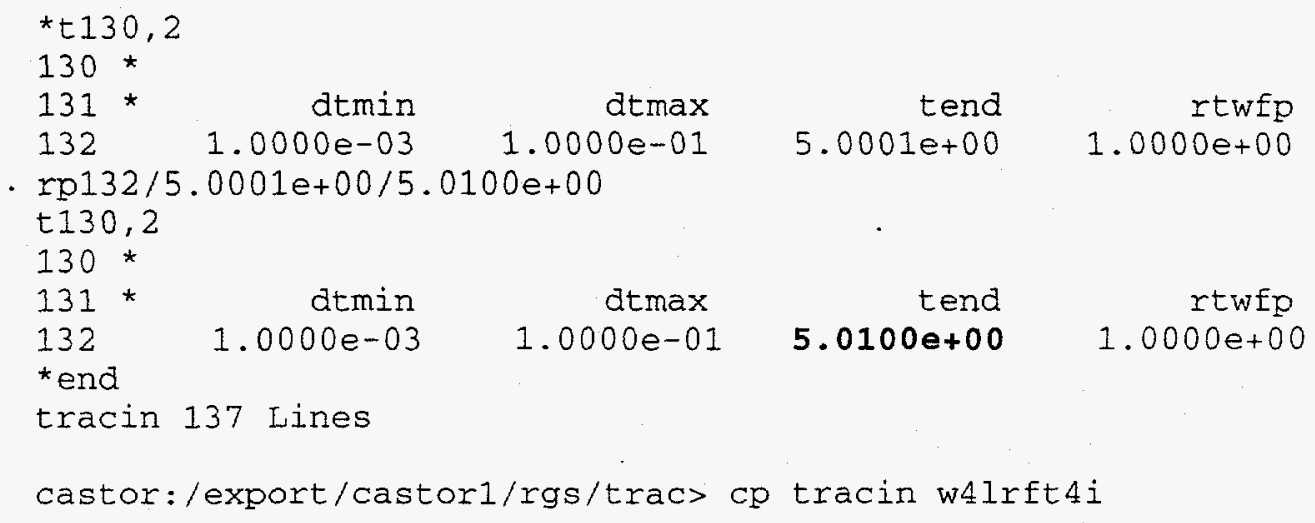




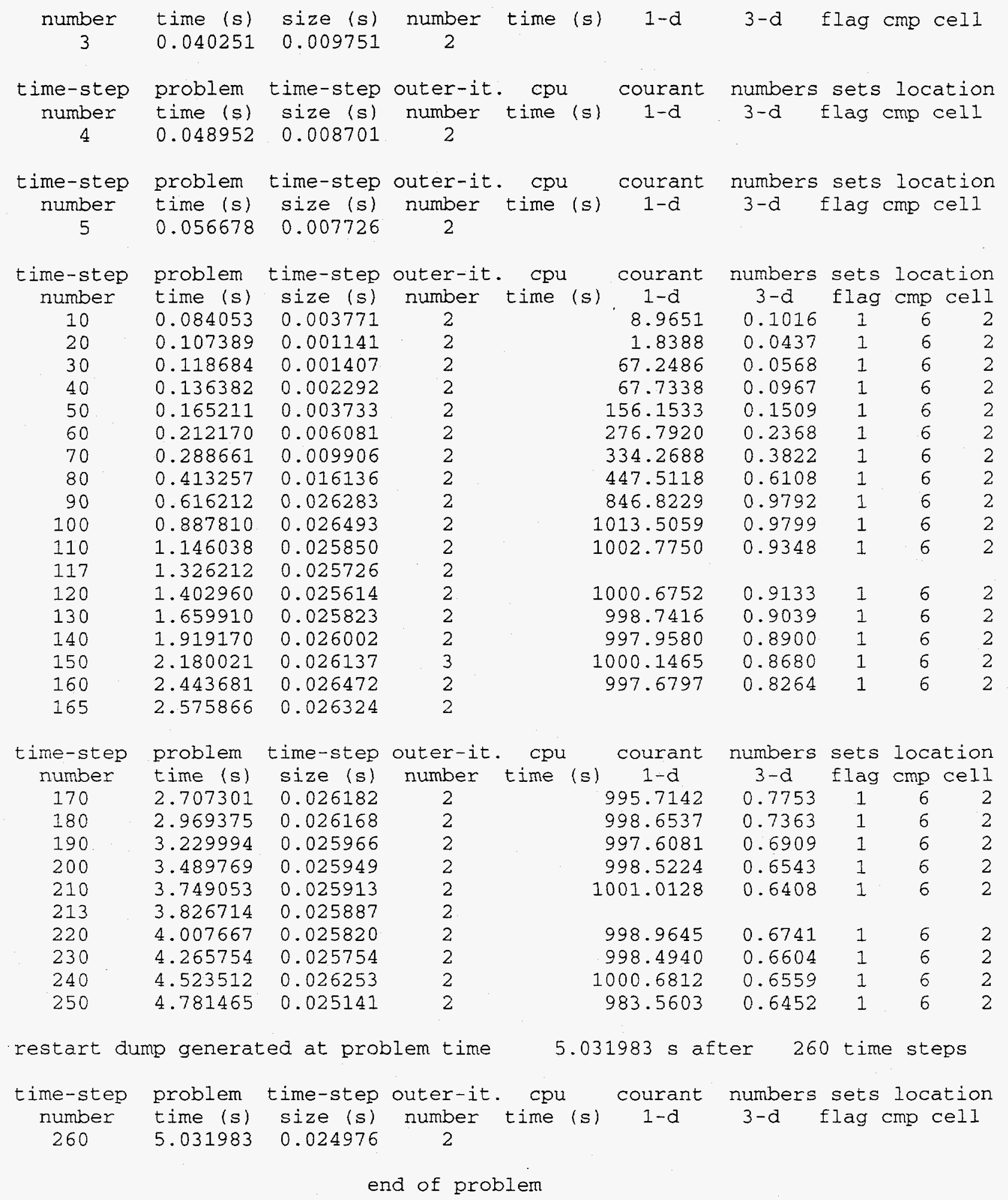

computative timing statistics

cpu time is $s$

castor:/export/castor1/rgs/trac> mv trcout w4lrft4o 
input data is being processed

h2o properties are used

restarting from final dump found at time-step number 165 and time $0.00000 \mathrm{~F}+00 \mathrm{~s}$ restarting time reset to $1.00000 \mathrm{E}+00 \mathrm{~s}$

restart dump generated at problem time $\quad 1.000000 \mathrm{~s}$ after 0 time steps

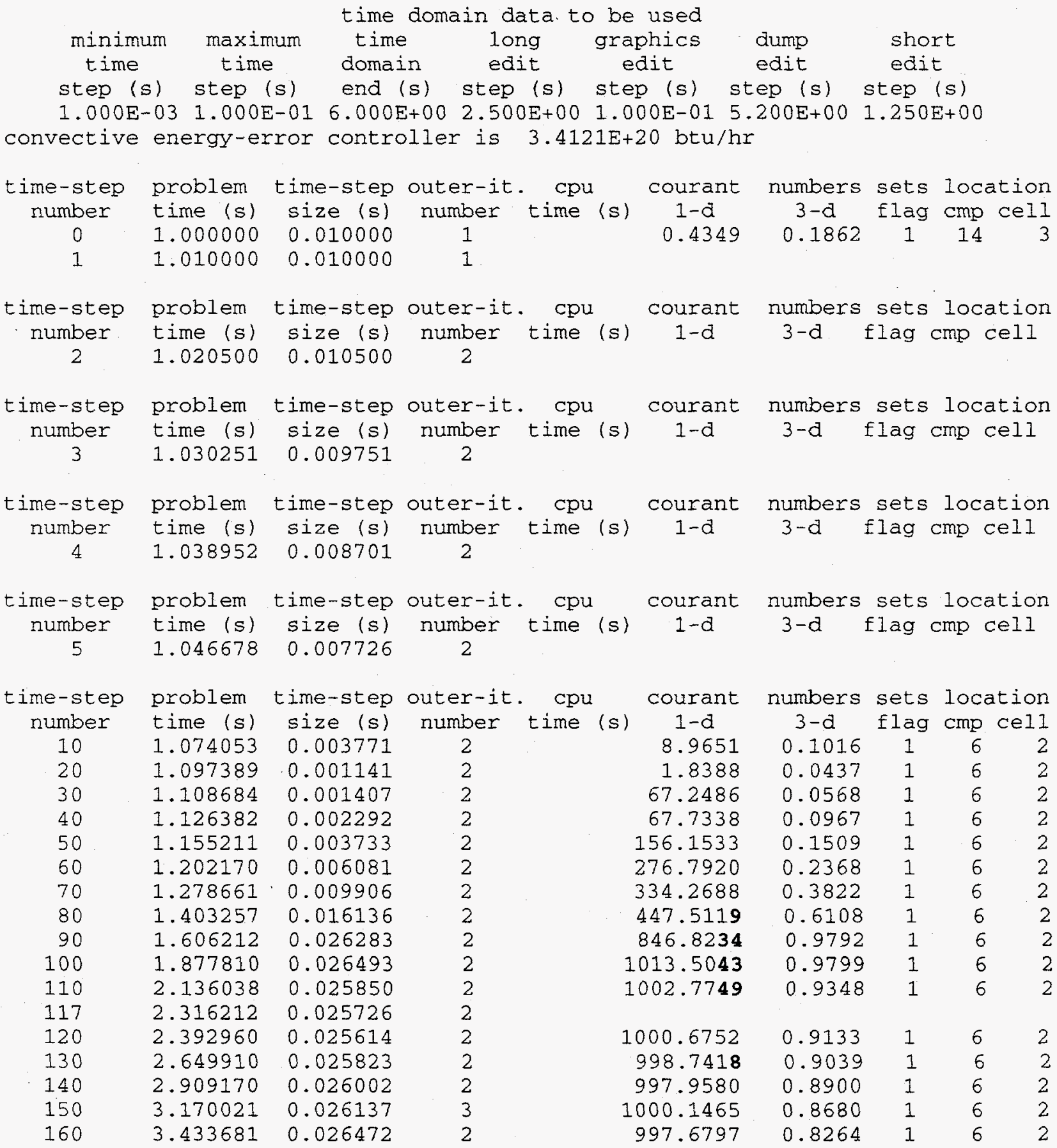




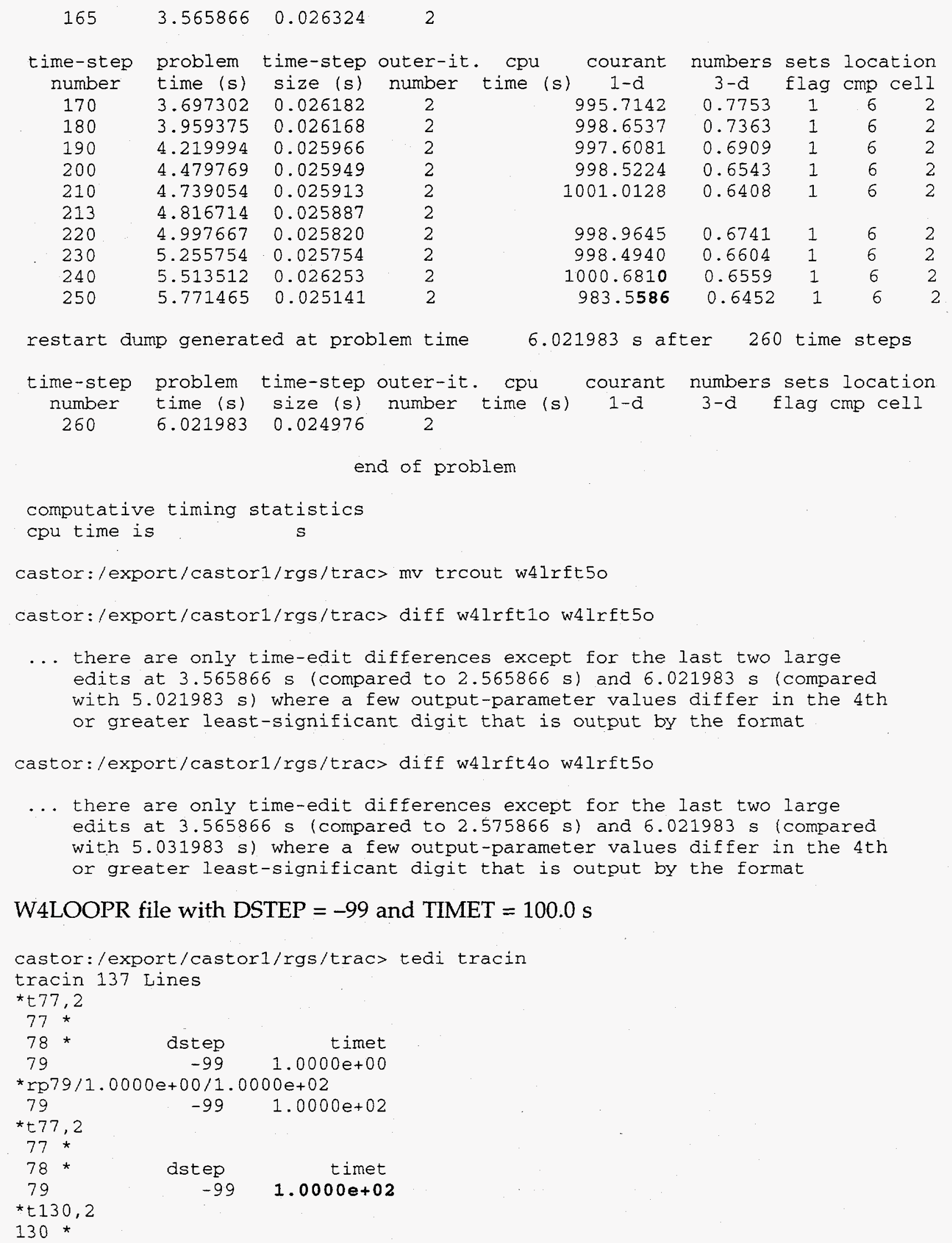

W4LOOPR file with DSTEP $=-99$ and TIMET $=100.0 \mathrm{~s}$ 


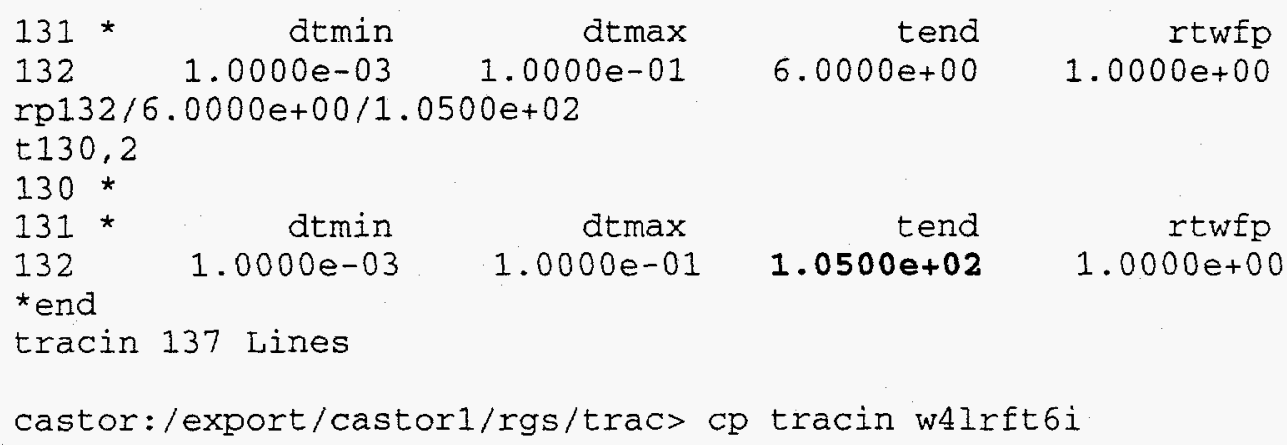

W4LOOPR terminal output based on DSTEP $=-99$ and TIMET $=100.0 \mathrm{~s}$

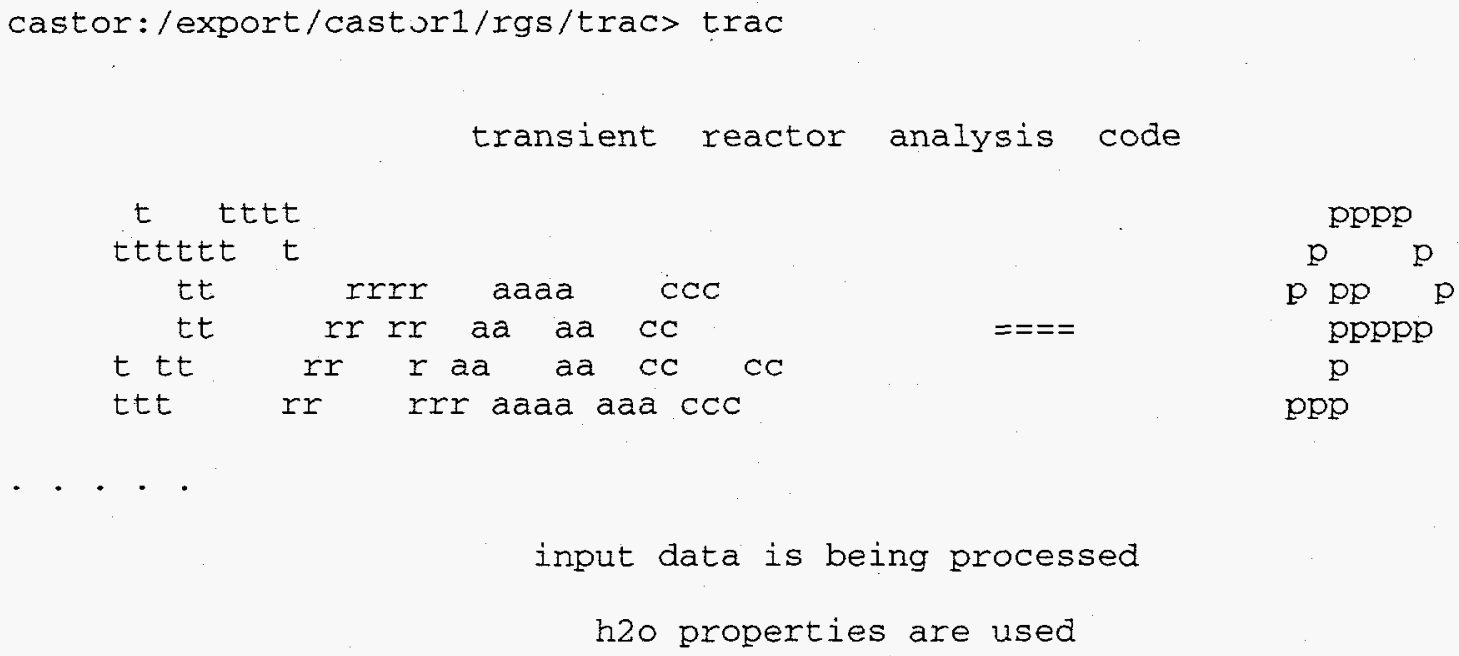




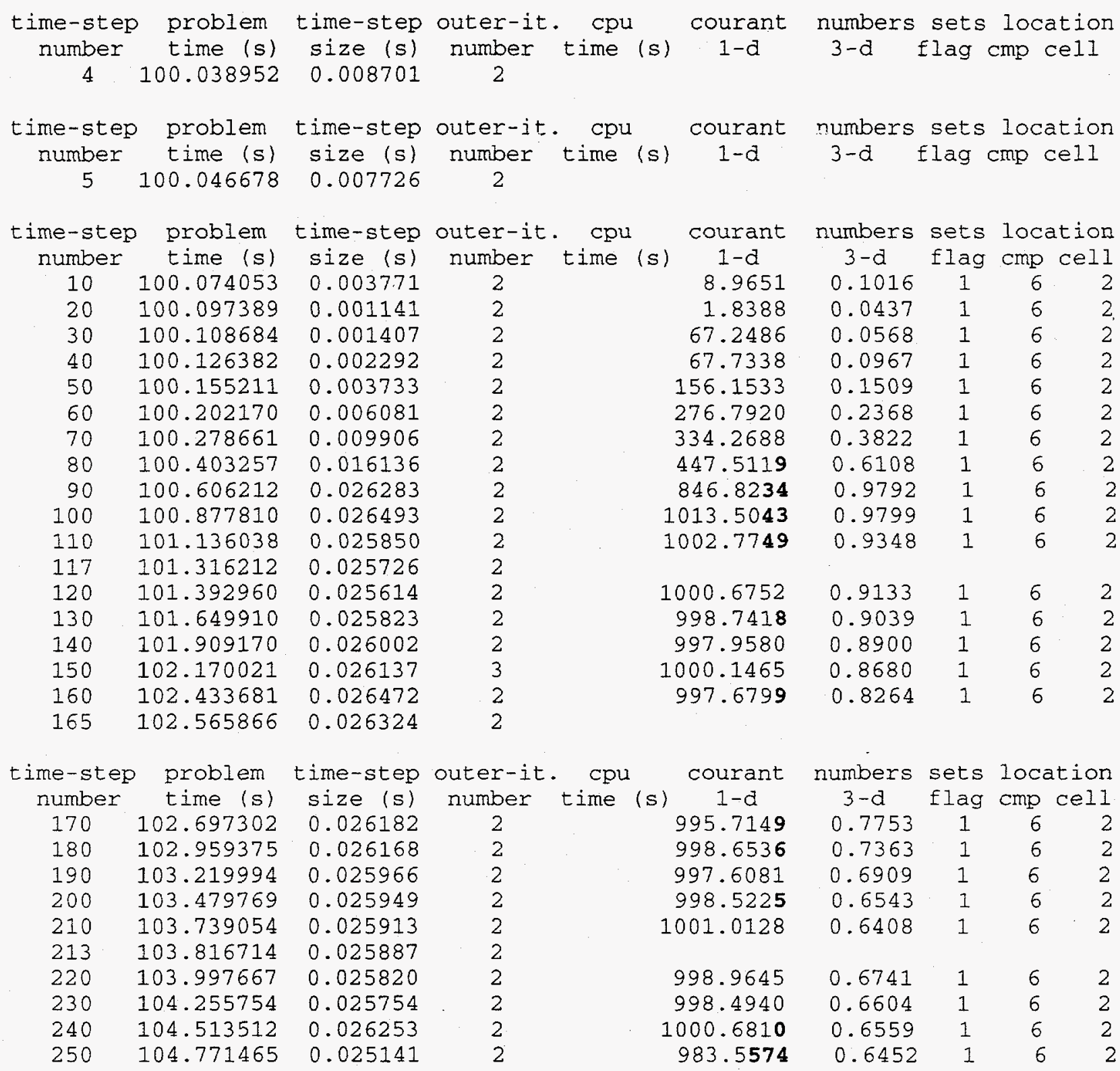

restart dump generated at problem time $105.021983 \mathrm{~s}$ after 260 time steps

time-step problem time-step outer-it. cpu courant numbers sets location number time (s) size (s) number time (s) 1-d 3 -d flag cmp cell $\begin{array}{llll}260 & 105.021983 & 0.024976 & 2\end{array}$

end of problem

computative timing statistics

cpu time is. $s$

castor:/export/castor1/rgs/trac> mv trcout w4lrft6o

castor:/export/castorl/rgs/trac> diff w4lrft10 w4lrft6o 
... there are only time-edit differences except for the last two large edits at $102.565866 \mathrm{~s}$ (compared to $2.565866 \mathrm{~s}$ ) and $105.021983 \mathrm{~s}$ (compared with $5.021983 \mathrm{~s}$ ) where a few output-parameter values differ in the 4 th or greater least-significant digit that is output by the format

castor:/export/castor1/rgs/trac> diff w4lrft5o w4lrft6o

... there are only time-edit differences except for the last two large edits at $102.565866 \mathrm{~s}$ (compared to $3.565866 \mathrm{~s}$ ) and $105.021983 \mathrm{~s}$ (compared with $6.021983 \mathrm{~s}$ ) where a few output-parameter values differ in the 4 th or greater least-significant digit that is output by the format

W4LOOPR file with DSTEP $=-99$ and TIMET $=10000.0 \mathrm{~s}$

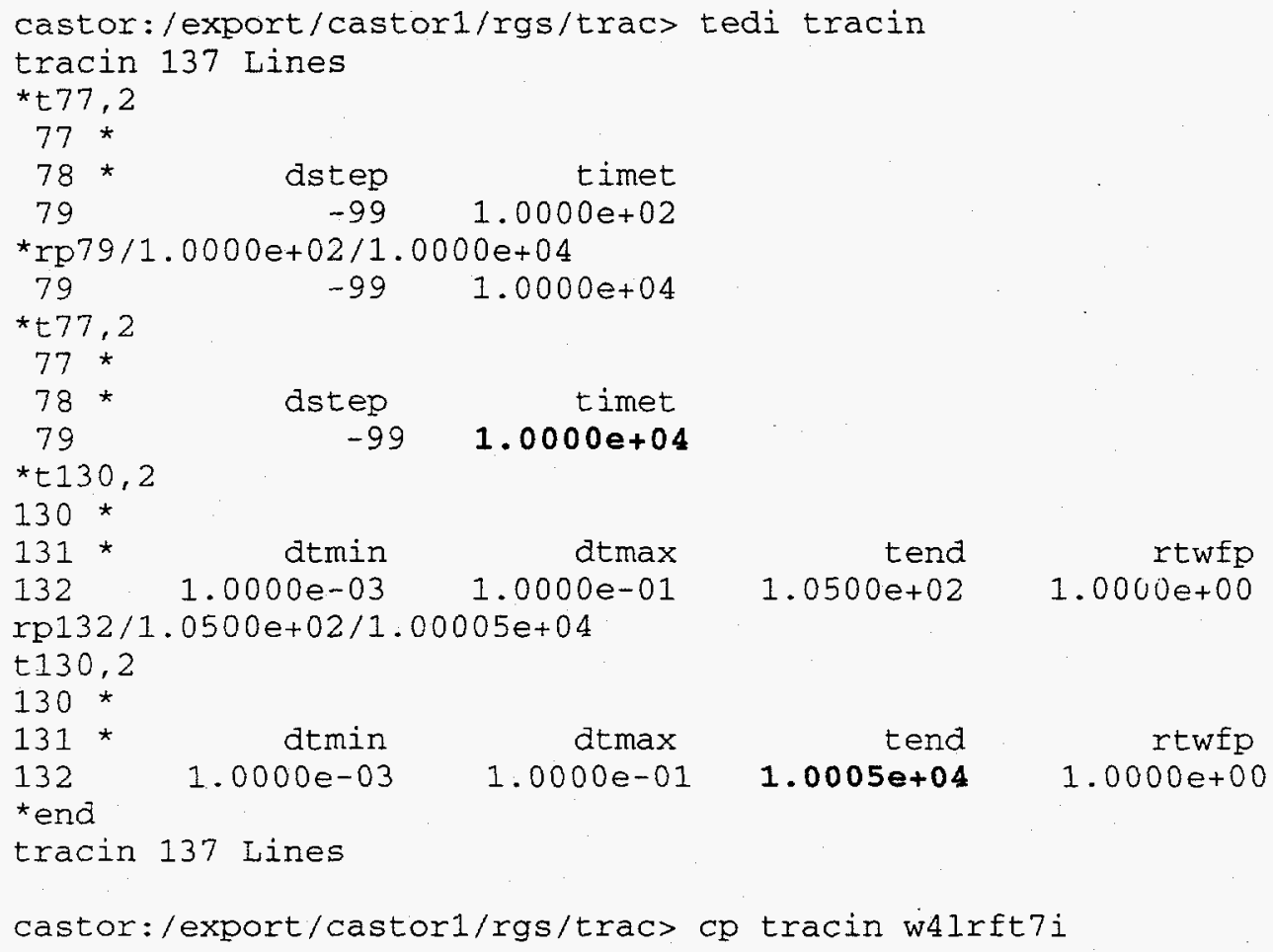

W4LOOPR terminal output based on DSTEP $=-99$ and TIMET $=10000.0 \mathrm{~s}$ castor:/export/castor1/rgs/trac> trac

transient reactor analysis code

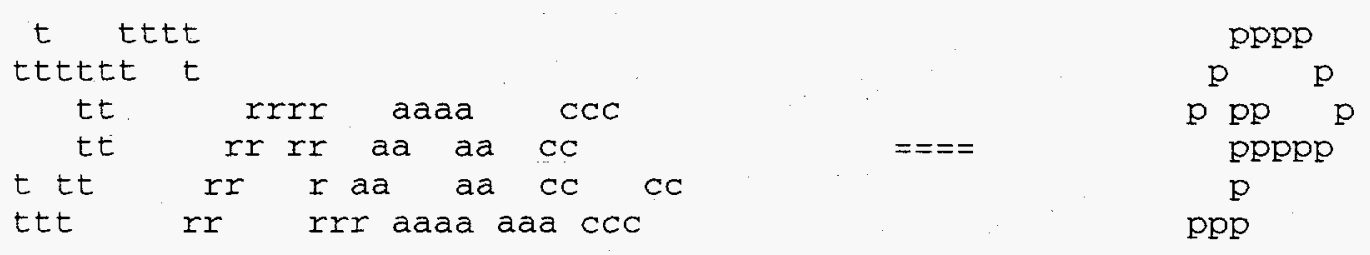

input data is being processed 
restarting from final dump found at time-step number 165 and time $0.00000 \mathrm{E}+00$ s restarting time reset to $1.00000 \mathrm{E}+04 \mathrm{~s}$

restart dump generated at problem time $10000.000000 \mathrm{~s}$ after 0 time steps

\begin{tabular}{|c|c|c|c|c|c|c|}
\hline $\begin{array}{l}\text { minimum } \\
\text { time }\end{array}$ & $\begin{array}{l}\text { maximum } \\
\text { time }\end{array}$ & $\begin{array}{l}\text { time dom } \\
\text { time } \\
\text { domain }\end{array}$ & $\begin{array}{l}\text { in data } \\
\text { long } \\
\text { edit }\end{array}$ & $\begin{array}{l}\text { be used } \\
\text { graphics } \\
\text { edit }\end{array}$ & $\begin{array}{l}\text { dump } \\
\text { edit }\end{array}$ & $\begin{array}{l}\text { short } \\
\text { edit }\end{array}$ \\
\hline step (s) & step (s) & end (s) & step (s) & step (s) & step (s) & step (s) \\
\hline $1.000 \mathrm{E}-03$ & $1.000 \mathrm{E}-01$ & $1.000 E+04$ & $2.500 E+00$ & $1.000 E-01$ & $5.200 E+00$ & $1.250 \mathrm{E}+00$ \\
\hline
\end{tabular}

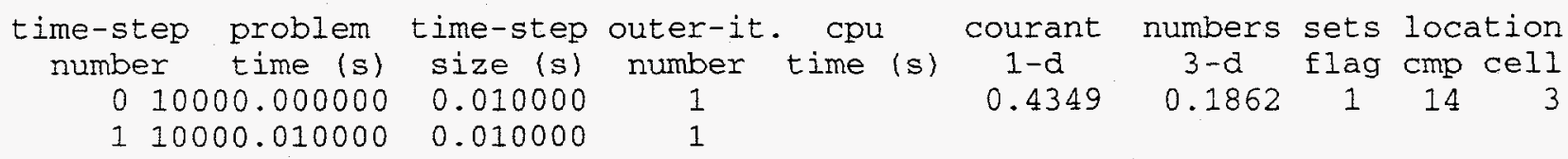

time-step problem time-step outer-it. cpu courant numbers sets location number time (s) size (s) number time (s) $1-d \quad 3-d$ flag cmp cell $210000.020500 \quad 0.010500 \quad 2$

time-step problem time-step outer-it. cpu courant numbers sets location number time (s) size (s) number time (s) 1-d 3-d flag cmp cell $310000.030251 \quad 0.009751 \quad 2$

time-step problem time-step outer-it. cpu courant numbers sets location number time (s) size (s) number time (s) 1-d 3-d flag cmp cell $410000.038952 \quad 0.008701 \quad 2$

time-step problem time-step outer-it. cpu courant numbers sets location number time (s) size (s) number time (s) $1-d \quad 3-d$ flag cmp cell $\begin{array}{llll}5 & 10000.046678 & 0.007726 & 2\end{array}$

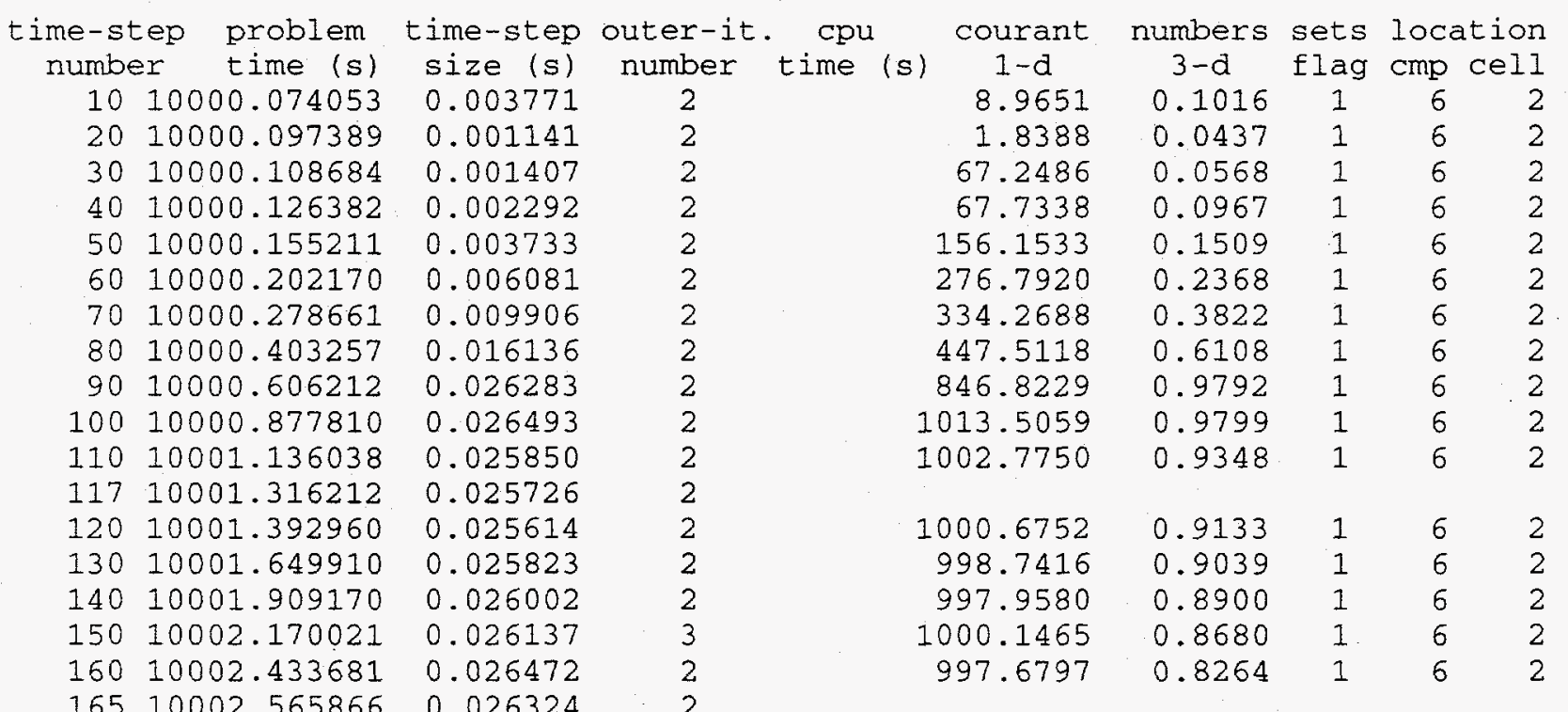




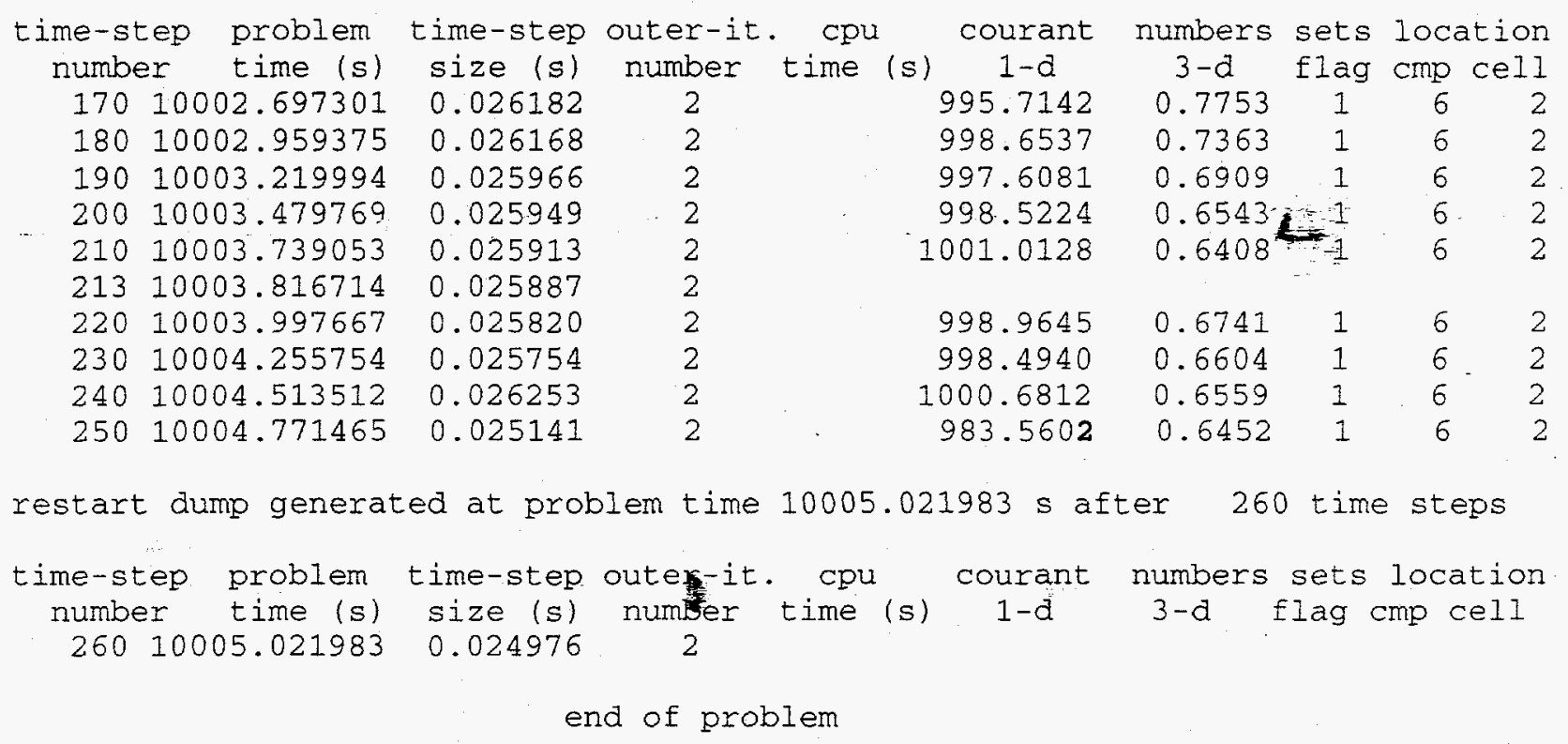

computative timing statistics

cpu time is

$s$

castor:/export/castor1/rgs/trac> mv trcout w4lrft7o

castor:/export/castorl/rgs/trac> diff w4lrft1o w4lrft7o

... there are only time-edit differences except for the last two large edits at $10002.565866 \mathrm{~s}$ (compared to $2.565866 \mathrm{~s}$ ) and $10005.021983 \mathrm{~s}$ (compared with $5.021983 \mathrm{~s}$ ) where a few output-parameter values differ in the 3 th or greater least-significant digit that is output by the format

castor:/export/castorl/rgs/trac> diff w4lrft6o w4lrft7o

... there are only time-edit diffenences except for the last two large edits at $10002.565866 \mathrm{~s}$ (compared to"102.565866 s) and $10005.021983 \mathrm{~s}$ (compared with $105.021983 \mathrm{~s}$ ) where a few output-parameter values differ in the 3 th or greater least-significant digit that is output by the format 